\title{
Democracy in America at Work: The History of Labor's Vote in Corporate Governance
}

\author{
Ewan McGaughey*
}

\begin{abstract}
Can there be democracy in America at work? The historical division between democracy in politics and hierarchy in the economy is under strain. Hierarchical interests in the economy are shifting their model of power into politics, and yet a commitment to revive the law is resurgent. Central examples are the proposed Accountable Capitalism Act, Reward Work Act, Workplace Democracy Acts, and Employees' Pension Security Acts. They would create a right for employees to elect $40 \%$ of directors on $\$ 1$ billion company boards, a right for employees to elect one-third of directors on other listed company boards and require one-half employee representation on single-employer pension plans. All challenge long held myths: that labor's involvement in corporate governance is foreign to American tradition, that when codified in law, labor voice is economically inefficient; that the legitimate way to have voice in the economy is by buying stocks; or that labor voice faces insurmountable legal obstacles. This Article shows these myths are mistaken, by exploring the history and evidence from 1861. The United States has one of the world's strongest traditions of democracy at work. Economic democracy has not been more widespread primarily because it was suppressed by law. Americans favor voice at work, while asset managers who monopolize shareholder votes with "other people's money" enjoy no legitimacy at all. This Article concludes that, even without the federal government, and by recreating themselves as laboratories of democracy and enterprise, states can adapt the current proposals and rebuild a living law.
\end{abstract}

* Senior Lecturer, School of Law, King's College, London. Research Associate, Centre for Business Research, University of Cambridge. Please contact at ewan.mcgaughey@kcl.ac.uk or @ewanmcg for discussion. I am deeply grateful to UC Berkeley, Center for the Study of Law and Society, David Caron, Rosann Greenspan, Jill Fisch, Mark Gergen, Anne Sheehan, Brishen Rogers, Charlotte Garden, Jed Kroncke, David Webber, Katherine Van Wezel Stone, Teresa Ghilarducci, and Leo Strine. While I am honored to draw on "other people's knowledge," all errors are mine. 


\section{INTRODUCTION}

In 1921 the author of America's modern economic constitution, Adolf A. Berle, wrote that "labor could control," and this "dream" could be realized if workers and unions controlled their enterprises, by having stock "tied to the job." Over his career Berle changed his mind. ${ }^{2} \mathrm{He}$ advocated tax to encourage diversified investments (not concentrated risk) in a "wider distribution of stocks" through pensions or mutual funds (not tied to the job). When everyone had a stake in the future, stockholding enabled "rationalized wealth distribution ... serving the American ideal of a just civilization." With labor rights to limit the "power of corporate managements with respect to wages and labor relations,"3 democracy in the economy would follow the "corporate revolution," just as democracy in politics followed the industrial revolution. ${ }^{4}$ In the Great Society's twilight, the goal of modern corporate law was to work in the interests of the ultimate investor, as labor law's goal was the interests of the worker. In the end, they were the same: the people of a democracy in America at work. $^{5}$

Today, as economic crisis has lurched toward political rupture, commitment to the kind of economic constitution that Berle once dreamt of is resurgent. Four proposed laws provide central examples. First, the Accountable Capitalism Act of 2018 would require that $40 \%$ of boards in $\$ 1$ billion companies be elected by employees. ${ }^{6}$ Second, the Reward Work Act of 2018 would ensure one-third of listed company board seats are

1. Adolf A. Berle, Jr., How Labor Could Control, New Republic, Sept. 7, 1921, at 37, 38.

2. $C f$. Adolf A. Berle, JR., POWer Without Property 52-55 (1959) (warning against asset managers using other people's money emerging as "a permanently concentrated group of officials building a paramount and virtually unchallenged power position over the American industrial economy."); Adolf A. Berle, JR., StUdies IN tHE LAW OF Corporate FinANCE 39 (1928) (suggesting that if "trust companies were in the habit of accepting, on 'custodian account,' deposits of stocks from small shareholders, thereby gathering many small holdings into an institution commanding a block so large that protection was worthwhile, and that they also provided themselves with power to represent the depositors of stock. Such institutions could easily keep themselves informed as to the affairs of the corporation ... and, as representing their clients, could take the action necessary to prevent or rectify violations of property rights.").

3. Adolf A. Berle, Jr., Property, Production and Revolution, 65 CoLuM. L. ReV. 1, 10 (1965).

4. Adolf A. Berle, Jr. \& Gardiner C. Means, The Modern Corporation and Private PROPERTY 67 (Macmillan 1933) (1932) ("With the corporate revolution, this quality has been lost to the property owner much as it has been lost to the worker through the industrial revolution.").

5. Cf. Franklin D. Roosevelt, Campaign Address on Progressive Government at the Commonwealth Club in San Francisco, California (Sept. 23, 1932) ("Democracy ... is a quest, a never-ending seeking for better things.").

6. Accountable Capitalism Act, S. 3348, 115th Cong. § 6 (2018). This would also require federal charters for $\$ 1$ billion companies (not a necessity for the operation of other provisions) and require political donations to have approval of $75 \%$ of the board and shareholders. 
elected by employees. ${ }^{7}$ These are unprecedented proposals in federal law: the United States would join the majority of countries in the Organization for Economic Co-operation and Development (OECD) with laws for voice at work. ${ }^{8}$ Third, the Workplace Democracy Acts, whose provisions have been reintroduced in Congress in varying forms, including the Employees' Pension Security Act of 2009, ${ }^{9}$ would require one-half representation of employees on the boards of every single-employer pension plan. ${ }^{10}$ Fourth, the latest version of the Workplace Democracy Act of 2018 would also restore the capacity for sectoral collective bargaining, ban discrimination against union members, and prevent employers from misrepresenting their staff as independent contractors to avoid tax and labor rights. ${ }^{11}$

These proposals to revive corporate governance meet direct challenges: historical, economic, political, and legal. First, a story has been told, notably by labor law scholar Clyde Summers, that votes at work are foreign and the United States had "no experience with employee representation on corporate boards." 12 Second, it is assumed that laws to protect workers' votes in the economy damage efficiency because, according to business scholars Michael Jensen and Bill Meckling, such laws are "less efficient than the alternatives which grow up and survive in a competitive environment." 13 Third, it has been argued as a matter of political principle, by figures like Louis Kelso, that the only legitimate way

7. Reward Work Act, S. 2605, 115th Cong. § 3(c)(2) (2018); H.R. 6096, 115th Cong. § 3(c)(2) (2018).

8. The majority of OECD countries (currently 19 out of 36) have some form of law requiring worker representation on company boards. See the map in Ewan McGaughey, Votes at Work in Britain: Shareholder Monopolisation and the 'Single Channel,' 47 InDUS. L.J. 76, 81 (2018). The United Kingdom's Conservative government reformed most recently, requiring from January 2019 that listed companies comply or explain with employee involvement, including having at least one worker representative on boards. Fin. REPORTING COUNCIL, U.K. CORPORATE GOVERNANCE CODE 5 (July 2018), https://www.frc.org.uk/getattachment/88bd8c45-50ea-4841-95b0-d2f4f48069a2/2018UK-Corporate-Governance-Code-FINAL.PDF [https://perma.cc/WF8L-U68T]

9. Employees' Pension Security Act of 2009, H.R. 4281, 111th Cong. (2009); see also Employees' Pension Security Act of 2008, H.R. 5754, 110th Cong. (2008); Employees' Pension Security Act of 2005, H.R. 4055, 109th Cong. (2005).

10. Workplace Democracy Act of 1999, H.R. 1277, 106th Cong. (1999); see also Workplace Democracy Act of 1997, H.R. 2012, 105th Cong. (1997); Workplace Democracy Act of 1995, H.R. 1355, 104th Cong. (1995); Workplace Democracy Act of 1992, H.R. 5126, 103d Cong. (1994); Workplace Democracy Act of 1992, H.R. 6041, 102d Cong. (1992).

11. Workplace Democracy Act, H.R. 5728, 115th Cong. (2018); Workplace Democracy Act, S. 2142, 114th Cong. (2015) (reintroduced 2018).

12. Clyde W. Summers, Codetermination in the United States: A Projection of Problems and Potentials, 4 J. COMP. CORP. L. SEC. REg. 155, 155 (1982) ("The United States has had no experience with employee representation on corporate boards, apart from the small number of employee-owned enterprises.").

13. Michael C. Jensen \& William H. Meckling, Rights and Production Functions: An Application to Labor-Managed Firms and Codetermination, 52 J. Bus. 469, 473 (1979). 
to have voice in corporate governance is by buying stocks. ${ }^{14}$ And fourth, the case has frequently been made that, even if legislators wanted, legal obstacles from federal preemption to antitrust make a more democratic economy unlawful. ${ }^{15}$ The purpose of this Article is to show that these challenges - and all challenges like them-are misplaced: democratic voice in the economy is embedded in American tradition; efficient, legitimate (and even without federal) law reform could be written into states today.

Part I uncovers the remarkable history of democracy in America at work: in corporate board rooms, pension governance, and work councils, which the labor movement drove. It concentrates on four historical periods, from 1861 to 1916 , to 1946, to 1980, and to today. As a matter of history, far from there being "no experience" with workers on boards, since 1919 the United States has had (however forgotten) the world's oldest law continually in force for worker participation in corporate governance. ${ }^{16}$ Against all obstacles, unions have had unparalleled success in getting collective agreements that put workers in boardrooms. The United States has one of the world's most sophisticated systems of pension board governance. ${ }^{17}$ As a matter of economics, the concentration of voting power in the hands of the asset managers who control votes on shares, far from growing up "in a competitive environment," has only been possible by law suppressing collective bargaining and the voice in labor's capital. The law exacerbates labor's inherent inequality of bargaining power, which starts with inequality in the distribution of property. ${ }^{18}$ Corporate

14. E.g., LOUIS O. KELSO \& MORTIMER J. AdLER, THE CAPITALIST MANIFESTO 153, 167 (1958). ("government should surround the economic status of the capitalist as stockholder with legal protections and privileges analogous to those it has conferred on the political status of the citizen, and for an analogous reason; namely, in order to make the capitalist, like the citizen, a man who can exert legal power in the control of his own affairs"); $c f .9$ COMM. ON INDUS. RELATIONS, FinAl REPORT AND TESTIMONY 8294 (1916).

15. Summers, supra note 12, at 157.

16. To compare Germany and the United Kingdom, see Ewan McGaughey, The Codetermination Bargains: The History of German Corporate and Labor Law, 23 COLUM. J. EuR. L. 135 (2016); McGaughey, supra note 8. The United Kingdom does have an older set of codetermination laws, for instance the Oxford University Act 1854, requiring staff voice in university governance, although universities do not (most of the time) have shareholders.

17. See generally DAVID WEBBER, THE RISE OF THE WORKING-ClASS SHAREHOLDER: LABOR'S LAST BEST WEAPON (2018).

18. Adam Smith, an Inquiry into the Nature and Causes of the Wealth of NATIONS $§ 12$ (1776) (enabling the wealthier party to "hold out" longer in any negotiation). A second cause is inequality in the ability to take collective action. JOHN STUART MiLl, PrinCIPLES OF POLITICAL ECONOMY $\S \S 8-12$ (1848). A third cause is inequality in information. WILLIAM STANLEY JEVONS, THE THEORY OF POLITICAL ECONOMY $\$ 74$ (3d ed. 1888). Unequal bargaining power is both a distributional and an efficiency problem (a fact that Ronald Coase and much "law and economics" theory attempts to deny), because unfair distribution affects the motivation to work. BERLE \& MEANS, supra note 4, at 122 ("In the operation of the corporation the controlling group even if they own a large 
governance today has become monopolized not even by shareholders, but by asset managers or banks, and all with "other people's money." 19 The evidence suggests this has deeply damaged efficiency and productivity and is uncompetitive.

Part II addresses the political arguments. As a matter of principle, there is no defensible theory, of "shareholder primacy" or otherwise, that justifies asset managers and banks monopolizing votes in the economy with other people's labor or "other people's money." ${ }^{20}$ Part III addresses the law. States could enact legislation that mirrors the current federal proposals. Neither the preemption doctrine, nor antitrust law, prevent states democratizing the economy through corporate law reform, not least because state and federal laws do it already. Until the Presidency and Congress regain their capacity to function and legislate, ${ }^{21}$ state governments can lead. They can revive as laboratories of enterprise, ${ }^{22}$ and recreate a living law that will restore democracy in America: a project still at work. It can be done again because it was before. The next part turns to how.

\section{THE HISTORY OF LABOR'S VOTE IN CORPORATE GOVERNANCE}

The principle of democracy at work was always part of the movement towards democracy in politics: an inseparable need to hold people in power accountable in every social institution. ${ }^{23}$ When Alexis de Tocqueville came to America, he wrote about a "strong and independent"

block of stock, can serve their own pockets better by profiting at the expense of the company than by making profits for it."); Alain Cohn, Ernst Fehr, Benedikt Herrmann \& Frédéric Schneider, Social Comparison in the Workplace: Evidence from a Field Experiment, 12 J. EUR. ECON. Ass'N 877 (2014); see also Ewan McGaughey, Behavioural Economics and Labour Law 7-9 (LSE Legal Studies, Working Paper No. 20/2014, 2014).

19. $C f$. Louis D. Brandeis, Other People's Money and How the Bankers Use It (1914); SMITH, supra note $18, \S 107$.

20. Theories of shareholder primacy assume shareholders bear residual risk in insolvency, when in fact the beneficiaries of pensions or mutual funds do: asset managers control votes on other people's money. See discussion infra Part II.

21. See Timothy Snyder, The Road to Unfreedom: Russia, Europe, America (2018); Martin Gilens \& Benjamin I. Page, Testing Theories of American Politics: Elites, Interest Groups, and Average Citizens, 12 PERSP. POL. 564 (2014) (Law reflecting people's preferences have been impossible at least since 1981.); Ewan McGaughey, Fascism-Lite in America (or the Social Ideal of Donald Trump), BRITISH J. AM. LEgAL StUD. (forthcoming 2018) (The decline of the democratic process wrought by the Supreme Court since Buckley v. Valeo, 424 U.S. 1 (1976).).

22. See New State Ice Co. v. Liebmann, 285 U.S. 262, 311 (1932) (Brandeis, J., dissenting) (A "[s]tate may, if its citizens choose, serve as a laboratory; and try novel social and economic experiments without risk to the rest of the country.").

23. $C f$. Thucydides, History of the Peloponnesian War 2 (Henry Dale ed., Harper and Bros. 1891) (ca 411 BC) (Pericles said, "Our government does not copy our neighbors, but is an example to them. It is true that we are called a democracy, for the administration is in the hands of the many and not of the few."). 
community, where the American citizen had "an interest in it because he shares in its management." ${ }^{24}$ In 1834, even though democracy was a privilege and freedom violently suppressed, Americans were still wedded to a kind of equality: they were relatively wary about a one-share, onevote norm that departed too far from democracy in capital ${ }^{25}$ and were attached to cumulative voting to represent multiple interest groups on corporate boards. ${ }^{26}$ Stockholders in this time of pre-democratic politics were the rich. They monopolized the votes in the economy. ${ }^{27}$ This did not mean the dominance of capital over labor went unchallenged.

\section{A. Towards Industrial Democracy? 1861 to 1916}

Abraham Lincoln challenged the old system. His call for a "government of the people by the people for the people" 28 was shaped by

\footnotetext{
24. See Alexis De Tocqueville, De la Démocratie en Amérique ch. 5 (1835).

25. See Alexander Hamilton, Final Version of the Second Report on the Further Provision Necessary for Establishing Public Credit (Report on National Bank) (Dec. 13, 1790) reprinted in 7 THE PAPERS OF AleXANDER HAMILTON 305, 334-39 (Harold C. Syrett \& Jacob E. Cooke eds., 1963) ("A vote for each share renders a combination, between a few principal [s]tockholders, to monopolise the power and benefits of the Bank too easy. An equal vote to each [s]tockholder, however great or small his interest in the institution, allows not that degree of weight to large stockholders, which it is reasonable they should have, and which perhaps their security and that of the bank require. A prudent mean is to be preferred."). After this, one-share, one-vote was dominant, but often with limits. JOSEPH G. BLANDI, MARYLAND BUSINESS CORPORATIONS 1783-1852, at 65-69 (1934) (40\% of charters issued between 1849 and 1852 instituting voting ceilings.); JOHN W. CADMAN, JR., THE CORPORATION IN NEW JERSEY: BusineSS AND Politics 1791-1875, at 309 (1949) (finding in New Jersey, 15\% of companies between 1796 and 1867 deviated from a one-ordinary-share, one-vote standard); Edwin Merrick Dodd, American Business Corporations Until 1860, 60 AM. HIST. REV. 620 (1954) (finding a general standard of a ten vote limit prevailed in most kinds of company); Alex Dreier, Shareholder Voting Rules in 19th Century American Corporations: Law, Economics and Ideology (Apr. 24, 1995) (unpublished manuscript) (on file with Yale Law School) (finding in Connecticut that $85 \%$ of charters between 1789 and 1856 adhered to a one-ordinary-share, one-vote norm); see also Colleen A. Dunlavy, Social Conceptions of the Corporation: Insights from the History of Shareholder Voting Rights, 63 WASH. \& LEE L. REV. 1347, 1361-65 (2006) (One-share, one-vote represented entrenchment of plutocratic power.); Henry Hansmann \& Mariana Pargendler, The Evolution of Shareholder Voting Rights: Separation of Ownership and Consumption (EGCI Law, Working Paper No 219/2013, 2013).

26. E.g., People ex rel. Stevenson v. Higgins, 15 Ill. 110 (1853) (concerning trustees of a hospital). Abraham Lincoln acted for Higgins. He lost on the point of who, precisely, was empowered by common law to exercise the right of removal. Lincoln argued that it should only be the legislature, the governor, or the Supreme Court, but not the hospital's trustees, but the court felt the trustees too could exercise the power of a motion.

27. See Victor Morawetz, A Treatise on the Law of Private Corporations $\S 251$ ( $2 \mathrm{~d}$ ed. 1886) ("It is frequently in the power of the corporation, through a majority vote of the shareholders, to remove the directors or managing agents who have failed in their duty."). It is noteworthy that stockholder control appeared firmly dominant also over director compensation. Id. § 508 (noting that it "would be contrary to established principles to allow the directors or other agents of a corporation to fix their own compensation.").

28. Abraham Lincoln, Gettysburg Address (Nov. 19, 1863), reprinted in THE PORTABLE ABRAHAM LinCOLN 295 (Andrew Delbanco ed., 1992).
} 
how Lincoln envisaged economic power in his first annual message as President in 1861. In a land torn by civil war, he warned against the "approach of returning despotism." 29 This came from "the effort to place capital on an equal footing with, if not above, labor in the structure of government" and the assumption that "a hired laborer is fixed in that condition for life." "Labor," said Lincoln, "is prior to and independent of capital. Capital is only the fruit of labor and could never have existed if labor had not first existed." 30

In the Emancipation Proclamation of 1863, Lincoln made the momentous step towards freedom of association, declaring all people who were enslaved to not only be free but also to have the right to work for "reasonable wages" and a guarantee of a job for "persons of suitable condition ... into the armed service." 31 Lincoln created the first public pensions in 1862, for disabled army personnel, ${ }^{32}$ and in 1865 it seemed he intended to go beyond, for all veterans. ${ }^{33}$ Over the trauma of the Civil War and assassination, this was the basis of a constitution, a house less divided, ${ }^{34}$ "which opens the way to all, gives hope to all, and consequent energy and progress and improvement of condition to all." 35

Between the end of the Civil War and the start of the First World War, three ideals that Lincoln embodied slowly took shape: (1) meaningful freedom of association, (2) growing prosperity in pay and pensions, and (3) growing commitment to an industrial democracy. All faced staunch opposition. In 1842, Commonwealth v. Hunt had already approved the

29. Abraham Lincoln, First Annual Message (Dec. 3, 1861), https://www.presidency.ucsb. edu/ws?pid=29502 [https://perma.cc/QRM6-SMWH].

30. Id.

31. Abraham Lincoln, Emancipation Proclamation (Jan. 1, 1863) ("I do order and declare that all persons held as slaves within said designated States and parts of States are and henceforward shall be free .... I hereby enjoin upon the people so declared to be free to abstain from all violence, unless in necessary self-defense; and I recommend to them that in all cases when allowed they labor faithfully for reasonable ... such persons of suitable condition will be received into the armed service of the United States.").

32. An Act to Grant Pensions, ch. 166, § 1, 12 Stat. 566 (1862) (Army personnel who had since March 4, 1861 been "disabled by reason of any wound received or disease contracted while in the service of the United States" were entitled.).

33. Abraham Lincoln, Second Inaugural Address (Mar. 4, 1865) in THE LITERARY WORKS OF ABRAHAM LINCOLN 273 (1942) (appearing to envisage an extension but was assassinated just a month later). He called "to bind up the nation's wounds, to care for him who shall have borne the battle and for his widow and his orphan, to do all which may achieve and cherish a just and lasting peace among ourselves and with all nations." Id.

34. $C f$. Abraham Lincoln, Speech in Acceptance of Nomination as United States Senator at the Illinois Republican State Convention, Springfield, Illinois (June 16, 1858) reprinted in THE ABRAHAM LiNCOLN ENCYCLOPEDIA (Mark E. Neely Jr. ed., Da Capo Press, Inc. 1982) (“A house divided against itself cannot stand. I believe this government cannot endure, permanently half slave and half free. I do not expect the Union to be dissolved - I do not expect the house to fall — but I do expect it will cease to be divided. It will become all one thing, or all the other."); Matthew 12:25.

35. Lincoln, supra note 29. 
right of labor unions to take collective action, ${ }^{36}$ abandoning English common law conspiracy theory in Massachusetts. ${ }^{37}$ But nationwide there were still three cases from 1842 to 1863 where unions on strike were held to be conspiracies. From 1863 to 1880 there were at least fifteen. ${ }^{38}$ In 1869 , the Knights of Labor organized the first major union federation, but though it committed to race and gender equality, it disavowed strikes. Also in 1869 , the Supreme Court tacitly ensured corporations engaged in interstate commerce had the right to freely establish and had mutual recognition. ${ }^{39}$ In 1875, American Express, then engaged in rail and post, started the first occupational pension, but without any worker voice. ${ }^{40}$ It aimed to compel worker loyalty. It asserted pensions were a gift that was made, not a right that was earned nor a fund that labor could control. ${ }^{41}$

The paucity of voice at work and in capital was not surprising; it was only in 1886 that the American Federation of Labor (AFL), which did assert the right to strike, was formed. ${ }^{42}$ The situation before then was captured by the U.S. Senate, Education and Labor Committee, led by Henry W. Blair from 1883-1885. It issued no final Report but gathered over 4000 pages of testimony from workers, unions, employers, journalists and activists. ${ }^{43}$ Southern workers were riven by deprivation following

36. Commonwealth v. Hunt, 45 Mass. (1 Met.) 111 (1842). The Boston Journeymen Bootmakers' Society was charged with a common law conspiracy, argued to have been received from English common law, for going on strike against employers who hired non-union workers that were receiving less pay. Chief Justice Shaw said there was no liability at common law because people "are free to work for whom they please, or not to work, if they so prefer .... [W] cannot perceive, that it is criminal for men to agree together to exercise their own acknowledged rights, in such a manner as best to subserve their own interests." Id. at 130. Note that a common law right to strike is further dependent on the invalidity of contracts excluding the right or requiring imbalanced notice periods before collective action can be taken. There would, of course, be little justification for a court to enforce such an agreement, since consent and true agreement would be absent, unless perhaps the workforce had negotiated a no-strike agreement through independent representatives.

37. See People v. Fisher, 14 Wend. 9 (N.Y. Sup. Ct. 1835) (holding it was an unlawful conspiracy to strike for higher wages); see also R v. Journeymen-Taylors of Cambridge (1721) 88 Eng. Rep. 9. The year after Fisher, Judge Edwards convicted a tailors' union for conspiracy on this precedent. The response was a meeting of 27,000 workers which burned effigies of them both. Outrage spread in the press. Edwin E. Witte, Early American Labor Cases, 35 YALE L.J. 825, 826-27 (1926).

38. Witte, supra note 37 , at 82.

39. See U.S. Const. art I, § 8, cl. 3 (the Commerce Clause); Paul v. Virginia, 75 U.S. 168 (1869) (holding that states were not allowed to attach special conditions to corporations doing interstate business but could regulate insurance contracts). See generally Frederick Tung, Before Competition: Origins of the Internal Affairs Doctrine, 32 J. CORP. L. 33 (2006).

40. William C. Greenough \& Francis P. King, Pension Plans and Public Policy 27 (1976).

41. Steven A. Sass, The Promise of Private Pensions: The First Hundred Years 22-24 (1997).

42. Selig Perlman, A History of Trade Unionism in the United States 118-24 (1922).

43. Gordon B. MCKinney, Henry W. Blair's Campaign to Reform America: From the CIVIL WAR TO THE U.S. SENATE 110-11, 132-40 (2012) (giving an excellent summary of Blair's engagement over the years). 
emancipation without any meaningful property reform. ${ }^{44}$ This fact was entrenched by the Supreme Court in the Civil Rights Cases of 1883, deciding that desegregation of public services was "unconstitutional." 45 The timeless dissent of Justice John Marshall Harlan urged that this left people's civil rights "practically at the mercy of corporations and individuals wielding power under the States." 46 Northern workers were struggling to secure basic wages, reduce their working hours, and have the freedom to take collective action. ${ }^{47}$ Pensions were barely mentioned, except for one witness who, though lucky enough to have a pension, said that he laughed when people asked him if it was enough to support a family. ${ }^{48}$

There were flickers of the future. ${ }^{49}$ A witness before the Committee named George Storm, of cigar manufacturer Straiton \& Storm, explained how from 1879 he introduced an arbitration board - with four employee and four management representatives, and one "neutral" representativeto ensure wages or work conditions were "settled upon a fair basis." ${ }^{50}$ His employees belonged to unions, but he testified there were no strikes since the board of arbitration began. He was adamant that it should never be a replacement for unions and called employers who imagined it could be "tricksters." " This was not equal representation on a board of directors, but it was still remarkable. If we take Storm at his word, it was a microcosm of joint industrial councils operating with collective bargaining. ${ }^{52}$

The Senate Labor Commissioners' proposed reforms were limited: they began from an almost blank slate. Blair pushed to extend federal

44. Id. at 111 .

45. See generally The Civil Rights Cases, 109 U.S. 3 (1883) (Harlan, J., dissenting).

46. Id. at 55 .

47. MCKINNEY, supra note 43, at 133-34.

48. 3 COMM. ON EDUC. \& LABOR, 48Th CONG., Report of THE COMMITTEE OF THE SENATE Upon the RELATIONS BeTweEn LABOR AND CAPITAL AND TESTIMONy TAKEN By THE COMMITTEE 395 (Comm. Print 1885) [hereinafter REPORT ON LABOR AND CAPITAL] (testimony of Edward L. Davenport).

49. StUART D. BRANDES, AMERICAN WELFARE CAPITALISM: 1880-1940, at 121 (1976) (noting that shop committees existed in 1833 but not where).

50. REPORT ON LABOR AND CAPITAL, supra note 48, at 803-19 (testimony of George Storm).

51. Id. at 806. (George Storm: "I have had employers come to me to inquire about this method of arbitration, and how it worked, and, after taking all the trouble to explain it to them, they would say in a sly manner, 'Well, I suppose you have it all your own way, don't you?' These people are unfit to have arbitration - they are tricksters. In speaking of arbitration, we must, therefore, leave all such people out of account.").

52. RAYMOND L. HOGLER \& GUILlERMO J. GRENIER, EMPLOYEE PARTICIPATION AND LABOR LAW IN THE AMERICAN WORKPLACE 15 (1992) (recording that from 1898 a Boston retail clothing store called William Filene's Sons, run by Edward A. and A. Lincoln Filene, delegated responsibility for welfare, lunchroom and entertainment, and then from 1901 gave seats on an arbitration board. They say, however, this was mainly as a mechanism to preempt collective bargaining with the union.). 
spending in education, particularly in the south, and for labor unions to have legal personality. The education measures stalled amidst the campaigns for Senate reelection in $1884 .{ }^{53}$ An Act did pass for unions to incorporate, but they showed no interest. ${ }^{54}$ The most lasting reform was the Bureau of Labor Statistics Act of $1884 .^{55}$ But another fight soon opened up: the Sherman Act of 1890 was meant to stop business combinations acting in restraint of trade; instead, its first use was against labor unions. In 1894, Chicago railroad workers struck against the Pullman Palace Car Co.'s emaciating wage cuts, ostensibly to cope with the drop in orders from economic depression. ${ }^{56}$ For instance, the monthly wage of a painter, Mr. Rhodie, was cut from $\$ 65.28$ in May 1893 to $\$ 12.52$ by Christmas. None of the managers' salaries were reduced. ${ }^{57}$ If this was not enough, many Pullman staff were housed by the Pullman Co., thus paying it rent. Wage cuts with rent hikes meant employees got into debt, and so were chained to the company. For all practical purposes, they were indentured labor.

The American Railway Union opposed the Pullman management because its principles stated "employees are entitled to a voice in fixing wages and in determining the conditions of employment." ${ }^{, 58}$ For exercising the right to strike, the ARU leader and future socialist presidential candidate, Eugene Debs, was imprisoned by an Illinois court, supposedly enforcing a Sherman Act injunction. ${ }^{59}$ The decision was later upheld by the United States Supreme Court in In re Debs on even broader grounds. ${ }^{60}$

53. MCKINNEY, supra note 43, at 139-40.

54. An Act to Legalize the Incorporation of National Trades Unions, 29 U.S.C. $\S \S 21-25$ (1886) (repealed 1926); U.S. Strike Comm'N, Report On the ChicAgo Strike OF JunE-July, 1894, S. EXEC. DOC. No. 7, at liii (1895).

55. An Act to establish a Bureau of Labor, ch. 127, 23 Stat. 60 (1884).

56. U.S. STRIKE COMM'N, supra note 54, at xxxiv ("The testimony of the Pullman company ... has left its claim ... in such loose and indefinite shape as to compel the conclusion that the reduction in the repair department was not made with reference to these depression results, but was part of a plan designed to reduce wages in every department to the lowest point possible to be reached in the department most seriously affected by the depression. Some reduction of wages in all departments was of course proper ... but a uniform reduction as between departments so differently situated in reference to revenue as the car-building and repair departments was not relatively just and fair toward the repair-shop employees.").

57. Id.

58. U.S. STRIKE COMM'N, supra note 54, at 148 (Eugene Debs quoting the American Railway Union's "declaration of principles").

59. United States v. Debs, 64 F. 436 (C.C.N.D. Ill. 1894) (imposing an injunction on the striking workers of the Pullman Company).

60. In re Debs, 158 U.S. 564 (1895) (holding that the federal government could enforce the injunction as part of its right to regulate interstate commerce, without considering the Sherman Act of 1890). But see Loewe v. Lawlor, 208 U.S. 274 (1908) (endorsing the imposition of damages on unions). From a competition law perspective, see generally Herbert Hovenkamp, Labor Conspiracies in American Law, 1880-1930, 66 TEX. L. REV. 919 (1988). 
Troops were sent into Chicago and shot thirty people. The subsequent inquiry by the United States Strike Commission concluded that, instead of trying to resolve disputes, the courts were still "poring over the laws of antiquity in order to construe conspiracy out of labor unions." In his evidence, Debs argued that "Government ownership of the railroads is decidedly better for the people than railroad ownership of [the] Government." ${ }^{1}$ Ultimately he favored, not state socialism, but "a cooperative commonwealth as a substitute for the wage system." ${ }^{2}$ The Strike Commission recommended, more modestly, a government panel to resolve disputes and wages, analogous to the Interstate Commerce Commission. ${ }^{63}$ But the courts continued imposing liability on unions, ${ }^{64}$ and did little (until 1911) to stop capital combinations. Spurred by the Sherman Act, the largest merger wave in United States history was unfolding. ${ }^{65}$ Another Industrial Commission appointed by Congress reported on labor relations in 1902 and finally recommended that state laws begin to enact labor rights, particularly by reducing working time. ${ }^{66}$ The Supreme Court's answer in 1905 was Lochner v. New York, ensuring most economic and social experiment was "unconstitutional." 67

With labor rights suppressed, few employees had surplus savings for pensions. But as the problems of old-age poverty spread, so did experiments. ${ }^{68}$ Only one witness to the 1895 Strike Commission advocated pensions for all rail workers. ${ }^{69}$ Some employers acted: by 1901, the Chicago and Northwestern Railway Company had five officials running a $\$ 200,000$ fund, but all were employer-appointed. ${ }^{70}$ Courts asserted that employers were "voluntarily" setting aside "a portion of its profits

61. U.S. STRIKE COMM’N, supra note 54, at 163.

62. Id. at 170 .

63. Id. at Lii (recommending a three-member strike commission, plus a union representative, to settle "disputes between railroads and their employees similar to those vested in the Interstate Commerce Commission as to rates, etc.").

64. E.g., Vegelahn v. Guntner, 167 Mass. 92 (1896) (Finding a union picket to be tortious intimidation. In dissent, Justice Holmes said, "Combination on the one side is patent and powerful. Combination on the other is the necessary and desirable counterpart, if the battle is to be carried on in a fair and equal way.”). (1991).

65. See generally HERBERT HOVENKAMP, ENTERPRISE AND AMERICAN LAW, 1836-1937 ch. 20

66. 19 U.S. INDUS. COMM’N, FinAL REPORT OF THE INDUSTRIAL COMMISSION 948 (1902).

67. See Lochner v. New York, 198 U.S. 45 (1905) (playing out the consequences of Allgeyer $v$. Louisiana, 165 U.S. 578 (1897)).

68. F. Spencer Baldwin, The Work of the Massachusetts Commission on Old Age Pensions, 85 PUBliCATIONS AM. STAT. Ass'N 417 (1909) (remarking that there were no official statistics on the extent of deprivation).

69. US STRIKE COMM'N, supra note 54, at 678.

70. E.g., George G. Tunell, The Pension System of the Chicago and Northwestern Railway Company, 9 J. POL. ECON. 271 (1901). 
belonging to shareholders," ${ }^{, 71}$ not giving employees pay for their work. ${ }^{72}$ In 1904 President Theodore Roosevelt extended a state pension to all army veterans who reached age $65,{ }^{73}$ but for retirement security almost everyone else had to turn to private markets. One option was life insurance. In 1905, this became the focus of the Armstrong Commission, with Charles Evans Hughes as chief counsel. Equitable Life had hosted an opulent party for a policyholder that caught media attention. The Commission uncovered patterns of bribes, mismanagement, and self-dealing. The New York legislative response was merely to limit insurers' rights to own shares, control banks, or invest in securities, but not to create a public system of social security. ${ }^{74}$ In 1909, Louis Brandeis tried to launch a different initiative in Massachusetts. ${ }^{75}$ Insurance, he said, had become "legalized robbery." "76 He promoted a voluntary "social alternative." But though he consulted three hundred unions, the scheme attracted few subscribers. ${ }^{77}$

On the other hand, a growing number of states - partly inspired by a Massachusetts commission ${ }^{78}$ and the United Kingdom's Old Age Pension Act 1908- started pensions for public sector workers, particularly teachers. ${ }^{79}$ Yet the courts were ready to strike down reform. In 1914, Arizona had a popular initiative and a referendum for a new pension scheme to cover everyone. ${ }^{80}$ In State Board of Control v. Buckstegge, the

71. McNevin v. Solvay Process Co., 32 A.D. 610 (N.Y. App. Div. 1898) endorsed in Menke v. Thompson, 140 F.2d 786 (8th Cir. 1944). This view expired by the time of ERISA in 1974. See Howell v. United States, 775 F.2d 887 (7th Cir. 1985).

72. Cf. McNevin v. Solvay Process Co., 32 A.D. 610 (N.Y. App. Div. 1898) (Green, J., dissenting) ("A promise, founded upon a valuable consideration inuring to the benefit of a promisor, to pay a sum of money upon specified contingencies, is not a promise to make a gift, even though the parties call it so . . . it constitutes a contract founded upon a valuable consideration.").

73. Executive Order No. 78 extended the Disability Pension Act 1890 which had recast the previous 1862 law. See Peter Blanck, Civil War Pensions and Disability, 62 OHIO ST. L.J. 109, 12427 (2001).

74. Mark J. Roe, Foundations of Corporate Finance: The 1906 Pacification of the Insurance Industry, 93 COLUM. L. REV. 639, 656-57 (1993).

75. For an interesting biographical comparison, see Paul Brickner, Different Styles and Similar Values: The Reformer Roles of Charles Evans Hughes and Louis Dembitz Brandeis in Gas, Electric, and Insurance Regulation, 33 IND. L. REV. 893 (2000).

76. Louis D. BRANDEIS, LifE InSURANCE: ThE ABUSES AND THE REMEDIES: AN AdDRESS Delivered BeFore THE COMMERCIAl Club of Boston (1905).

77. Louis D. Brandeis, Massachusetts Savings-Bank Insurance and Pension System, 11 PUBliCATIONS AM. STAT. Ass'N. 409 (1909) (optimistically arguing this "social alternative" avoided the "compulsory" nature of the German pension, and unlike National Insurance in the UK, the need to buy insurance individually would both make "workingmen independent," and avoid "burdening general taxation").

78. Report of the Massachusetts Commission on Old Age Pensions, AnNuities and INSURANCE (1910).

79. See W. CARSOn Ryan, JR. \& Roberta King, DeP'T of THE InTERIOR, Bureau Of EduC., State PENSION Systems For PubliC-SCHOOL TEACHERS 5-8 (1916).

80. An Act Providing for an Old Age and Mothers' Pension and Making Appropriation Therefor, 1914 Leg., Reg Sess. (Ariz. 1914) (winning a massive $67.57 \%$ of the vote). 
Arizona Supreme Court declared it "unconstitutional" because there was no means testing. Chief Justice Henry D. Ross argued that apparently a "taxpayer ought not to be made ... to help pay pensions to those who have enough" because he could "think of no principle of law or justice that could be invoked ... that required him to do so." $" 81$

Although courts' aggression to labor grew in Debs, Lochner, and Buckstegge, Congress began to act. It established a Commission on Industrial Relations in 1912, after two renegade union members dynamited the Los Angeles Times building. ${ }^{82}$ The Commission led directly to the Clayton Act of $1914 \S 6$, proclaiming the "labor of a human being is not a commodity or article of commerce," and removing labor from antitrust liability. ${ }^{83}$ Samuel Gompers, the American Federation of Labor President, said it was "the Magna Carta of America's workers." ${ }^{84}$ But just as fast, Coppage v. Kansas held over powerful dissent that state laws, which prohibited employers demanding that workers forgo the right to a union, were "unconstitutional." 85 "No union or no job" was the choice that the Supreme Court gave American workers until the Wall Street Crash.

The Commission's later hearings gave valuable insight into three fundamentally different views over the future of economic governance, represented by three key witnesses: JD Rockefeller, Andrew Carnegie, and Louis Brandeis. First, Rockefeller, the oligarch of Standard Oil, which was broken up in $1911,{ }^{86}$ was brought to the Commission because of a strike at his Colorado Fuel \& Iron Co. In April 1914, company guards machinegunned twenty-five people, including eleven children, camped in tents. He displayed contrition and hired William MacKenzie King, the ex-Canadian Minister of Labor and Canadian Prime Minister from 1921 to 1930 and 1935 to 1948 , to consult on resolving the unrest. Rockefeller promised to introduce a board of workers and managers where "questions affecting conditions of employment can be discussed and grievances examined." 87 Rockefeller's own directors opposed even this. ${ }^{88}$ So did the United Mine

81. State Bd. of Control v. Buckstegge, 158 P. 837, 842 (Ariz. 1916).

82. The United States labor movement, including Gompers and Debs, initially believed the two accused McNamara brothers were innocent, until they finally pleaded guilty in the trial. See Eugene V. Debs, The McNamara Case and the Labor Movement, 12 INT'L SOCIALIST REV. 397 (1912); see also Herbert Shapiro, The McNamara Case: A Crisis of the Progressive Era, 59 S. CAL. L.Q. 271 (1977).

83. 15 U.S.C. $\S 17$ (2012).

84. Samuel Gompers, Labor and the War: The Movement for Universal Peace Must Assume the Aggressive, 21 AM. FEDERATIONIST 849, 860 (1914).

85. Coppage v. Kansas, 236 U.S. 1 (1915).

86. Standard Oil Co. of New Jersey v. United States, 221 U.S. 1 (1911).

87. 8 COMM. ON INDUS. RELATIONS, FINAL REPORT AND TESTIMONY 7766 (1916).

88. RAYMOND L. HOGLER \& GUILLERMO J. GRENIER, EMPLOYEE PARTICIPATION AND LABOR LAW IN THE AMERICAN WORKPLACE 21-25 (1992). 
Workers of America because it was "not a union and can never be recognized as such by the American labor movement ... an organization so created and so controlled." ${ }^{\prime \prime}$ Indeed, Rockefeller had no intention of working with unions. He wanted to replace them and privatize freedom of association. The plan's constitution explicitly said, "officials of the company may decide any question without consulting committees or employees' representatives." 90

Second, as a more enlightened and thoughtful representative of business, Andrew Carnegie gave evidence. The popular Scottish rail and steel magnate had often said the "man who dies thus rich dies disgraced" and that "the millionaire will be but a trustee of the poor." 91 He was a trustee of Cornell University from 1890 but was equally tarnished by labor conflict from the Homestead Strike of 1892, where twelve people were killed and twenty-three had been injured. Carnegie defended himself by saying, "I drew the line at contract breaking," that it "was the first time I had found labor, ... ready to break a contract," (dictated by the employer) "and it was the last." 92 Yet it was clear that, while Carnegie charmed the Commission and the audience ${ }^{93}$ and reminisced about the supposedly "great times" he had doing collective bargaining, ${ }^{94}$ he was committed to reform. Initially, Carnegie spoke of workers becoming shareholders so

89. Id. at 26 (quoting the Denver Post (Sept. 26, 1915)).

90. Id. at 28 (quoting Ben M. SELEKMAN \& MARY VAN KLEEK, EMPLOYEES' REPRESENTATION In COAL Mines: A STUdy OF THE INDUSTRIAL REPRESENTATION PLAN OF COLORADO FUEL AND IRON COMPANY 291 (1924)).

91. Andrew Carnegie, Wealth, 148 N. AM. REv. 653, 653-64 (1889).

92. 9 COMM. INDUS. RELATIONS, FINAL REPORT AND TESTIMONY 8289 (1916).

93. Id. at 8294 shows a typical exchange:

Mr. Carnegie: Undoubtedly. I knew them by name, I delighted and you see behind my back they always call me Andy. I like that, and I would rather have it than "Andrew" or "Mr. Carnegie." There is no sympathy about that. But you have your men calling you

"Andy" and you can get along with them. [Laughter.]

Chairman Walsh: I have had no difficulty in restraining the expression of the audience until you came.

Mr. Carnegie: [Laughter.] That is all right.

Chairman Walsh: We must observe order.

Mr. Carnegie: Mr. Chairman, I congratulate you upon having such an audience and to see how many ladies are here. Do you know, one of the greatest triumphs in this age? It is the elevation of woman. [Laughter.]

Chairman Walsh: Ladies and gentlemen, if you will please keep quiet a few minutes I will ask Mr. Carnegie to repeat that sentence, as some of you may not have heard it. If you will keep quiet, I will ask him what it was. What was it that you said, Mr. Carnegie?

Mr. Carnegie: I want to tell you something, that I never can forget. I was traveling in China ....

94. Id. (Carnegie said he "was only too glad when the workmen came. I felt pretty sure that if they came to consult with me that we would part all right." This appears difficult to square with his later observation that if someone was "a director in the corporation he naturally would not hear of the trouble at the works and would not feel the responsibility."). 
that "workmen and capitalists" were "pulling and owning the same boat." 95 But after the Commission, the practical steps he took were to improve pensions and, critically, to give staff a voice in them. ${ }^{96}$ In 1915 , Carnegie asked Dr. Henry Pritchett, president of the Carnegie Foundation for the Advancement of Teaching, to create a new plan for universities, one that involved "some form of oversight" by the policyholders. ${ }^{97}$ Carnegie donated the startup capital for a new Teachers Insurance and Annuity Association (TIAA). Members elected a quarter of the twenty person board, albeit from nominees screened by a committee. ${ }^{98}$ TIAA's first board was appointed by the Carnegie Foundation, but then member representation was implemented with one trustee a year from 1921 to 1926.

Third, there was Louis Brandeis, the "people's lawyer." He argued that the "one cause" that was "fundamental" to industrial unrest was "the contrast between our political liberty and our industrial absolutism." "The individual employee," said Brandeis, "has no effective voice or vote." Large corporations made industrial absolutism inevitable, and instead the law should reform to follow what unions would achieve in collective agreements, if the playing field were fair. ${ }^{99}$ If there was one goal, it was "the attainment of rule by the people, and that involved industrial democracy as well as political democracy." ${ }^{100}$ Brandeis set out general principles, rather than specifics. In the end, the Commission's leading Report recommended reforms following the United Kingdom Trade Disputes Act $1906 ;{ }^{101}$ its model of industrial democracy was synonymous with collective bargaining, not writing rights to votes at work into law. Other Commissioners only recommended improvements to industrial arbitration. ${ }^{102}$ These options - votes at work, collective bargaining, and arbitration - set the essential frame of the debate on how labor law

95. Id. at 8288 ("When workmen were made shareholders they were sold shares in the company upon a very liberal basis and guarded against loss. I consider this the greatest of all steps forward yet taken for making workmen and capitalists fellow workmen indeed, pulling and owning the same boat. This can not fail to prove highly profitable to both."); cf. Andrew Carnegie, The Future of Labor, 33 ANNALS AM. ACAD. POL. SOC. SCI. 15, 17 (1909) (calling for workers as "part owners having a right to vote with their fellow-proprietors, and sharing in the profits").

96. See Richard L. Hannah, The Control of Pensions: A Brief History and Possibilities for the Future, 40 MGMT. DECISION 938, 939 (2000) (noting that Carnegie pre-funded his steel worker pensions, thus placing him at the progressive end).

97. William C. Greenough, It's My Retirement Money Take Good Care of It: The TIAA-CREF STORY 35 (1990).

98. Id.

99. COMM. INDUS. RELATIONS, supra note 87, at 7659-7700.

100. Id.

101. 1 COMm. Indus. RELATIONS, FinAl REPORT AND TESTIMONY 137 (1916) (using the U.K. Trade Disputes Act 1906 as a model for U.S. law).

102. Id. 
developed in the next thirty years. Brandeis wrote after the hearings, that to create a "living law," the ideal had been "[a] government of the people, by the people and for the people." Now it was "[d]emocracy and social justice." 103

\section{B. The Slow Deal: 1916 to 1946}

From the First World War to the end of the Second, America clearly became a more social democracy, but it was a slow deal. Three main shifts were that (1) workers' savings flooded the stock market, separating ownership and control of companies more than ever, and these new worker-shareholders had to fight against disenfranchisement; (2) the first worker representatives were placed on boards of directors, and this practice was even reflected in a Massachusetts Law of 1919; but (3) business tried to hijack the language of "industrial democracy" with sham work councils that shielded management authority. Labor fought back with collective bargaining, culminating in Roosevelt's New Deal.

The changes of labor's fortunes were fundamental causes of the Wall Street Crash and the Great Depression because the stock market was built on labor's capital. Even with the Clayton Act's minimal freedoms, prosperity grew, and people wanted to save for old age. While Lochner and Buckstegge suppressed statewide social security, the Tariff Act of 1913 reintroduced a progressive income tax ${ }^{104}$ and enabled employers to deduct pension payments and deferred annuity premiums as a business expense. ${ }^{105}$ The Civil Service Retirement Act of 1920 set up a model that many state governments, as employers, followed, while a trickle of private employers set up workplace pensions. The Revenue Act of 1921 exempted any profit sharing or stock bonus trust used "for the exclusive benefit of some or all . . . employees." ${ }^{106}$ By 1926, the Internal Revenue Service also exempted pension funds. ${ }^{107}$ When companies built up pension savings, they paid no tax until employees received and spent the money. Despite

103. Louis D. Brandeis, The Living Law, 10 ILL. L. REV. 461 (1916).

104. Pollock v. Farmers Loan \& Trust Co., 157 U.S. 429 (1895) (striking down the progressive income tax; however, in 1913 the Sixteenth Amendment was passed, discussed in Brushaber v. Union Pacific Railroad, 240 U.S. 1 (1916)).

105. This meant that smaller sums of profit were taxable. The Revenue Act of 1918 said that employers who separately constituted funds could claim deductions. SASS, supra note 41, at 102-03.

106. Revenue Act of 1921, Pub. L. No. 67-98, § 219(f), 42 Stat. 227, 247. The Act was primarily a tax cut initiative led by Andrew Mellon. Mellon had inherited his father's bank, diversified it into industry, acquired the position of Secretary of the Treasury, and became the third highest American taxpayer by the mid-1920s.

107. See Revenue Act of 1928, Pub. L. No. $70-562, \S 165,45$ Stat. 792, 839 (updated in 1932, 1934 and 1936; it also allowed deductions for past accumulations, but the deduction had to be spread over ten years); Revenue Act of 1926, Pub. L. No. 69-20, § 219(f), 44 Stat. 9, 33-34; Revenue Act of 1924, Pub. L. No. 68-176, § 219(f), 43 Stat. 253, 276-77. 
the tax reforms, most workers did not have the option of a workplace pension. ${ }^{108}$

For labor, workplace pensions were problematic. The law still framed pensions as a "gift." Employers threatened to withdraw workplace pensions if workers joined unions. This is why AFL President Samuel Gompers insisted that labor should control pensions alone until the government established an old age pension. ${ }^{109}$ But Arizona's public pension plan in 1916 was not the only one to be struck down. In 1923, a Nevada law was passed, but it was amended in 1925 so that counties could opt out. ${ }^{110}$ In 1925, the Pennsylvania Supreme Court struck down its fledgling state pension because apparently redistributing money for "benevolent" purposes was "unconstitutional."111 By 1929, only Montana's old age pension remained. Just 3.7 million U.S. workers had workplace pensions, around $10 \%$ of the non-agricultural labor force. Pensions that unions controlled were small and many failed during the Depression. ${ }^{112}$ In railways, where unionization was high, around $85 \%$ of people had pensions. But again, a substantial number were unilaterally reduced or closed when Wall Street crashed. ${ }^{113}$

Denied social security by their courts and denied workplace pensions by their employers, Americans had to save for old age somewhere else: the stock market. This drove the great separation of ownership and control

109. See Luther Conant JR., A Critical Analysis of Industrial Pension Systems 22 (1922) (Quoting Samuel Gompers, "Paternalism either in government or in industry is abhorrent. It takes away the initiative of the workers who should themselves prepare for old age .... Until the Government itself establishes an old age pension system, labor will insist that pension systems shall be controlled by the workers themselves, without any connection whatever with the employers.").

110. See Abraham Epstein, The American State Old Age Pension System in Operation, 170 ANNALS AM. ACAD. POL. \& SOC. SCI. 107, 107 (1933).

111. Busser v. Snyder, 128 A. 80, 83 (Pa. 1925); see also Ira Jewell Williams, The Attack Upon the Supreme Court, 7 Const. REv. 143, 239 (1923); Gifford Pinchot, Old Age Assistance in Pennsylvania: Righting the Neglects of Yesterday, 14 AM. LAB. LEGIS. REV. 288 (1924).

112. Murray WebB Latimer, Trade Union Pension Systems: AND Other SuPERANNUATION AND PERmanent AND Total Disability BENEFITS In the United STATES AND CANADA 8-9 (1932); SASS, supra note 41, at 125-27.

113. D. Shapiro, Employee Pensions in Collective Bargaining, 59 YALE L.J. 678, 680 (1950). Mellon's response to the crash in November 1929, according to Herbert Hoover, was to "liquidate labor, liquidate stocks, liquidate the farmers, liquidate real estate. It will purge the rottenness out of the system. High costs of living and high living will come down. People will work harder, live a more moral life. Values will be adjusted, and enterprising people will pick up from less competent people." Edward Gale Agran, Herbert Hoover and the Commodification of Middle-Class AMERICA 161 (2016). 
from 1916 to 1919 , later described by Gardiner Means. ${ }^{114}$ Workers saving for retirement flooded the stock market, which rocketed from $1916 .{ }^{115}$

Consistent data on stock market growth and pension savings in the early twentieth century are hard to find over time. ${ }^{116}$ However, we know that when public pension spending is higher (because the state replaces a proportion of income in retirement), people save less for retirement themselves. When the public pension is smaller (fixed at a minimum, safety-net level), people save more in occupational pensions, life insurance, mutual funds, and private savings. This money floods stock markets and creates a diversified shareholder base. This is why in OECD countries, as public pension spending rises, dispersion of shareholding falls. As the Figure 1 shows, countries like Germany or France with income-linked state pensions have many block shareholders. ${ }^{117}$ Countries like the United Kingdom or the United States with minimum statepensions have a massive dispersion of shareholders, as the blockholders are flooded out.

114. Gardiner C. Means, The Diffusion of Stock Ownership in the United States, 44, Q. J. ECON. 561, 562 (1930); see also 3 KARL MARX, CAPITAL: THE PROCESS OF CAPITALIST PRODUCTION AS A WHOLE 316 (Friedrich Engels ed., 1894) ("In stock companies the function [of appropriating labor] is divorced from capital ownership, hence also labour is entirely divorced from ownership of means of production and surplus-labour. This result of the ultimate development of capitalist production is a necessary transitional phase towards the reconversion of capital into the property of producers, although no longer as the private property of the individual producers, but rather as the property of associated producers, as outright social property."); Gardiner C. Means, The Separation of Ownership and Control in American Industry, 46 Q.J. ECON. 68 (1931).

115. See Marco Becht \& J. Bradford DeLong, Why Has There Been so Little Block Holding in America?, in A HISTORY OF CORPORATE GOVERNANCE AROUND THE WORLD: FAMILY BUSINESS Groups to Professional Managers 640 (Randall K. Morck ed., 2005) (charting data on the number of shareholders at AT\&T, Pennsylvania Railroad and U.S. Steel, taking off from 1916).

116. Raghuram G. Rajan \& Luigi Zingales, The Great Reversals: The Politics of Financial Development in the Twentieth Century, 69 J. FIN. ECON. 5, 15 tbl.3, 46 app. (2003) (Showing the "[e]volution of stock market capitalization over GDP." This shows, in snapshots of 1913, 1929, 1938, and so on, the dramatic growth in U.S. stock market capitalization, as well as the U.K., Germany and 22 other countries. Its use is difficult because GDP fluctuates. Ideally, stock market capitalization figures over time could be correlated with public pension spending over time.).

117. The data in Figure 1 comes from James Shinn \& Peter Gourevitch, Political Power and Corporate Control: The New Global Politics of Corporate Governance (2005). 
Figure 1

\section{Share ownership dispersion and public pension spending}

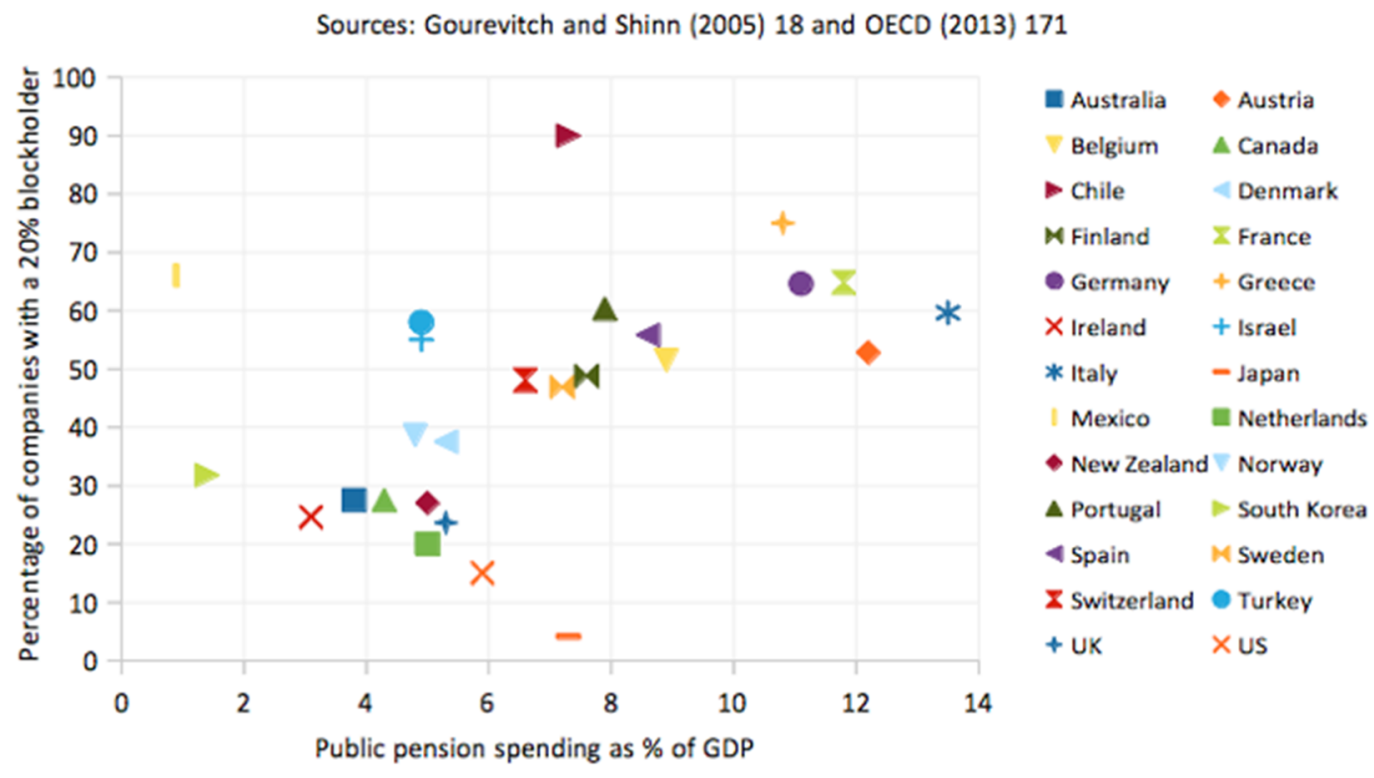

Before the Wall Street Crash, extraordinary investment growth meant a mass base of small investors. They lacked organization or bargaining power. By 1925, a growing number of companies had begun issuing nonvoting shares. ${ }^{118}$ Then, the Dodge Motor company was taken over by an investment bank, Dillon Read \& Co., ${ }^{119}$ and made a huge $\$ 160$ million share issue. Every share was nonvoting, and all of the shares were bought. Economist William Ripley led an outcry, ${ }^{120}$ saying nonvoting shares "strike at the very tap-root of our capitalistic system" because "power and responsibility must ever be yoked together," to stop the "absolute control by intermediaries - most commonly bankers." ${ }^{121}$ Many

118. W.H.S. Stevens, Stockholders' Voting Rights and the Centralization of Voting Control, 40 Q.J. ECON. 353, 355, 361 (1926) (Showing 16 issues of nonvoting shares in 225 companies, sometimes with no votes, sometimes with limited votes. In 1898, International Silver Co. issued stock with no votes until 1902 and restricted after.).

119. The Dodge brothers, from the notorious Dodge v. Ford Motor Co., 170 N.W. 668 (Mich. 1919), had just died.

120. William Z. Ripley (1867-1941) was a complicated figure, which probably accounts for him being less well known, despite the resonance of his work today. He was an overt xenophobe, viewing both black people and women as less than competent to exercise political rights. After the Wall Street Crash, which many people credited him with predicting, Ripley suffered a series of nervous breakdowns and retired in 1933.

121. William Z. Ripley, Two Changes in the Nature and Conduct of Corporations, 11 PROC. ACAD. POL. SCI. N.Y. 143, 143-46. (1926) reprinted in 67 CONG. REC. 7719. 
argued dispersed shareholders were unwilling or unworthy. Ripley replied that at least they "might always be stimulated to assert themselves," 122 and a rising corporate lawyer, Adolf A. Berle, added that at least with votes "there is always a latent power which can be exercised whenever the majority chooses to act." 123

The campaign was successful enough for Ripley to be invited by President Calvin Coolidge to the White House. ${ }^{124}$ On January 27, 1926, the New York Stock Exchange (NYSE) responded to the disenfranchisement outcry with a policy statement, that they would "give careful thought to the matter of voting control." This was eventually hardened into a rule after the New Deal. ${ }^{125}$ Even more, the new Securities and Exchange Commission (SEC) would eventually pressure the NYSE to issue Rule $452,{ }^{126}$ preventing brokers from voting on their depositors' shares without instructions, either on mergers or when it might "affect substantially the rights or privileges of such." 127 However, the SEC continued to allow voting upon "routine" matters, including an uncontested election for the board of directors. ${ }^{128}$

122. Stevens, supra note 117, at 383 (objecting that while bondholders claims to interest would be enforceable, the voteless shareholder has no enforceable right).

123. Adolf A. Berle, Jr., Non-Voting Stock and “Bankers' Control," 39 HARV. L. REV. 673, 675 (1926); see also Adolf A. Berle, Jr., Participating Preferred Stock, 26 Colum. L. ReV. 303, 306 (1926).

124. See William Z. Ripley, Main Street and Wall Street (1927) (introduced by Woodrow Wilson).

125. See Securities and Exchange Act of 1934, Pub. L. No. 73-291, § 19, 48 Stat. 881, 898-99 (enabling the SEC to oversee and veto NYSE rules). On May 7, 1940, a "Statement of Listing Requirements as to Preferred Stock Voting Rights" confidently proclaimed, "Since 1926, The New York Stock Exchange has refused to list non-voting common stock." Similarly, the Investment Company Act of 1940, Pub. L. No. 76-768, § 18, 54 Stat. 789, 817-21, required the capital structure in investment companies to be one-share, one-vote for common stock. Contra Joel Seligman, Equal Protection in Shareholder Voting Rights: The One Common Share, One Vote Controversy, 54 GeO. WASH. L. REV. 687, 698 (1986).

126. Securities and Exchange Act of $1934 \S 14(\mathrm{~b})$ regulates proxy voting.

127. Richard Maidman, Voting Rights of After-Record-Date Shareholders: A Skeleton in a Wall Street Closet, 71 YALE L.J. 1205, 1215 (1962); see also Aktiengesetz [AkGt] [German Stock Corporation Act] Law of Jan. 30, 1937, RGBL I (Ger.) (describing voting instructions); Mark J. Roe, Some Differences in Corporate Structure in Germany, Japan, and the United States, 102 YALE L.J. 1936, 1975, 1977 (1993) (arguing that "populist" reasons existed for U.S. banks becoming smaller, but does not explore this element of the law; the German experience with bank voting on deposited shares presents a stark contrast); Detlev F. Vagts, Reforming the "Modern" Corporation: Perspectives from the German, 80 HARV. L. REV. 23, 57 (1966) (noting comparisons with the Aktiengesetz $1965 \S 135)$.

128. 15 U.S.C. $\S 78 \mathrm{n}($ b) (Supp. 1965) gave authority for further rule making by the SEC, but nothing was done immediately. Broker voting typically supported management. See JAMES E. HEARD \& Howard D. SHERMAN, CONFLicts Of InTEREST IN THE PROXY Voting SYSTEM 22 (1987); Henry G. Manne, Some Theoretical Aspects of Share Voting, 64 CoLuM. L. REv. 1427, 1443 (1964). On the other, general aspects of Manne's work and its contemporary reception, see Adolf A. Berle, Modern Functions of the Corporate System, 62 COLUM. L. REV. 433-49 (1962). 
Although they were not completely disenfranchised, small shareholders still lacked information. The law did not guarantee that adequate information was disclosed about the securities they bought. After the fact, the dominant economic literature has theorized the Wall Street Crash was caused by a classic speculative bubble, ${ }^{129}$ or by the Federal Reserve's policy on money supply. ${ }^{130}$ At the time, the institutional cause of the speculative bubble, rather than human irrationality, was recognized to be the absence of disclosure regulation. The Securities Act of 1933directly inspired by Berle and Means's Book III-resolved this. ${ }^{131}$ The larger question was that, if that regulation had always been lacking before, why were the bubble and bust so tremendous this time? The answer is the historically unprecedented volume of American workers saving for retirement: Wall Street crashed labor's capital.

How did labor rights evolve from the War to the crash? In 1918, Eugene V. Debs had been sentenced to prison again, this time for opposing the war, ${ }^{132}$ and he ran on the Socialist ticket for President in 1920 from prison. "No job or no union" employment contracts remained common from Coppage v. Kansas until the Norris-La Guardia Act of 1932. Further, in 1921, Duplex Printing Press Co. v. Deering held the right to strike in solidarity with workers of other employers had no immunity under the Clayton Act. ${ }^{133}$

On the other hand, one year after entering World War One, on April 8, 1918, a National War Labor Board was established by the Department of Labor. ${ }^{134}$ To smooth war production and avoid strikes, ${ }^{135}$ it promoted work councils, collective bargaining, and arbitration, not as alternatives to one another but as complements. The Board had five representatives nominated by the National Conference Board, five by the American Federation of Labor, and two "public" representatives agreed to by each. ${ }^{136}$ It heard labor dispute appeals and had an inspectorate office to enforce agreed standards. It urged employers to set up work councils on the same

129. See generally John KenNeth Galbraith, The Great Crash ch. 10 (1954); John MAYNARD Keynes, THE General THEORY OF EMPLOYMENT INTEREST AND MONEY 149 (1936).

130. See generally Milton Friedman \& AnNa J. Schwarz, A Monetary History of the United STATES, 1867-1960 (1963) (arguing that the Great Depression's cause was that the government allowed the monetary supply to shrink, and it should have kept all banks going as the lender of last resort).

131. See generally BERLE \& MEANS, supra note 4, at 289-331.

132. Debs v. United States, 249 U.S. 211 (1919).

133. Duplex Printing Press Co. v. Deering, 254 U.S. 443 (1921) (holding that secondary strike action was unlawful because the Clayton Act of $1914 \S 20$ referred to immunity for trade disputes between an "employer and employees").

134. This was established as a separate entity in 1913 on the last day of the Taft presidency.

135. See generally Richard B. Gregg, National War Labor Board, 33 HARV. L. REV. 39 (1919). 136. Id. at 40 . 
model to settle disputes. ${ }^{137}$ To attain its goals, the Board had no express enforcement power, but was backed by the ability to withdraw government contracts and had emergency powers to commandeer factory production. ${ }^{138}$ From the Clayton Act of 1914 to the creation of the Board in 1918, union membership was growing and inequality shrinking. But at the end of the War, with Republicans winning the Senate election in November 1918, employers flouted its orders. On August 12, 1919, the Board was ended. ${ }^{139}$

Before the Board shut down, a remarkable law was passed putting workers on company boards. In April 1919, the newly elected Governor of Massachusetts, Calvin Coolidge, signed an Act that a "manufacturing corporation may provide by by-law for the nomination and election by its employees of one or more of them as members of its board of directors." This is still on the books today, in $\S 23$ of the Massachusetts Laws chapter on business corporations, ${ }^{141}$ and is therefore the world's oldest codetermination law continuously in force. The option was adopted in part by the Dennison Manufacturing Co. at Framingham, ${ }^{142}$ but in reality the law codified what had already become a growing social practice. By 1922, a Boston clothing store, William Filene's Sons, enabled employees to effectively choose four of the eleven members of the board of directors, a practice that emerged from growing employee involvement since $1898 .{ }^{143}$

137. See NAT'L Indus. CONFERENCE BD., Report No. 21, Works COUNCILS IN THE UNITED STATES 8 (1919).

138. Gregg, supra note 135, at 45.

139. Louis L. Jaffe, Post-War Labor Relations: The Contributions of the War Labor Board, 29 IOWA L. REV. 276 (1944) ("Not more than three years later the Steel Industry had smashed the Unions and underwritten the Open Shop Era of the Twenties. It is, of course, true that the Board worked out in considerable detail the meaning of the right to collective bargaining: it forbade individual contracts, discharge for union activity, etc. It thus gave concreteness to an idea which only a decade later bore fruit. It insisted on the 'living' or 'minimum' wage and one observer believed (in 1919) that it had established the principle as an 'actuality'; yet as we know it failed to educate the Supreme Court in this respect and certainly much of Industry remained unconverted.").

140. An Act to Enable Manufacturing Corporations to Provide for the Representation of Their Employees on the Board of Directors, 1919 Mass. Acts 45.

141. MASS. GEN. LAWS ch. 156, § 23 (2018); see also N.J. ReV. STAT. § 14.9:1-3 (1957) (repealed).

142. Calvert C. Magruder, Labor Copartnership in Industry, 35 HARV. L. Rev. 910, 915-19 (1921) (describing how the Dennison Manufacturing Company at Framingham, Massachusetts, with over 3000 staff, gave voting power to 368 managerial employees, while non-managers had voice in a consultative works committee).

143. RAYMOND L. HOGLER \& GUILlERMO J. GREINER, EMPLOYEe PARTICIPATION AND LABOR LAW IN THE AMERICAN WorKPLACE 15 (1992) (In 1898, William Filene's Sons had delegated responsibility to workers for welfare, running the canteen and entertainment, and from 1901 had allocated employee seats on an arbitration board. This would, however, be seen today as an illegal sham company union.); EARL J. MILLER, WORKMEN'S REPRESENTATION IN INDUSTRIAL GOVERNMENT 39-40 (1922) ("All employees, including salaried officials, by virtue of being employed in the store, are members of the Filene cooperative association.... There are eleven 
In other states, by 1919 there were at least two plans: at Procter and Gamble and at the General Ice Delivery Company of Detroit. ${ }^{144}$ A more complex arrangement, yet adopted by at least twenty companies by 1919 , was developed by John Leitch: workers elected a "House of Representatives," foremen a "Senate," top management a "Cabinet," and for a proposal to become "law," it had to pass all three. This was first employed at the Packard Piano Company in 1913, although its fate is unclear. ${ }^{145}$ Many of these systems tied employees to buy stocks, but not always. ${ }^{146}$ For example, in New York, the Dutchess Bleachery at Wappingers Falls had a five member board of directors, one appointed by a subsidiary board representing employees. ${ }^{147}$ Jett Lauck recorded that in 1926 there were at least eight companies with employee representation on a board of directors, five through voluntary action, and three through stock purchase. ${ }^{148}$ On these grounds alone, it is clear that Clyde Summers' opinion that the United States had "no experience with employee representation on corporate boards" went too far. ${ }^{149}$

Work councils were another form of representation, but after the War Labor Board was gone employers pushed to retool them as replacements for unions, not complements. In 1919, the National Industry Conference Board (NICB), the major American employer organization, ${ }^{150}$ found in a survey of 225 work council plans that 120 had been created under Federal government auspices and 105 on the employers' initiative. ${ }^{151}$ The NICB argued councils could quell labor unrest and improve productivity, but its

members on the Board of Directors. The employees nominate six members for this board, and the stock-holders of the company choose four from this panel of six. These four employee members have the same powers as the ones representing the employers.").

144. Neil M. Clark, Common Sense in Labor Management 28-29 (1919) (The Proctor \& Gamble plan was not yet instituted.).

145. Milton Derber, The Idea of Industrial Democracy in America: 1915-1935, 8 LAB. HIST. 3 (1967).

146. William O. Douglas \& Carrol M. Shanks, Cases and Materials on The LaW of MANAGEMENT OF BUSINESS UNITS 130-31 (1931) (Employee representation in management is not always associated with employee stock ownership.).

147. Id. at 130 .

148. See Jett W. Lauck, Political and Industrial Democracy 1776-1926, chs. 3 , 6 (1926); Paul F. Gemmill, The Literature of Employee Representation, 42 Q.J. ECON. 479, 492 (1928) (describing the five "torchbearers of industrial democracy" that "stand out above all others as indicating a sincerity of purpose and as offering a basis for future constructive action" as (1) William Filene's Sons, (2) the Dutchess Bleachery, (3) the Dennison Manufacturing Co., (4) the A. Nash Co., and (5) Philadelphia Rapid Transit Co.).

149. Clyde W. Summers, Codetermination in the United States: A Projection of Problems and Potentials, 4 J. COMP. CORP. L. SEC. REG. 155, 155 (1982) ("The United States has had no experience with employee representation on corporate boards, apart from the small number of employee-owned enterprises.").

150. This is now The Conference Board. It was established in 1916. The two other main lobby groups for employers are the Business Roundtable and the US Chamber of Commerce.

151. See generally NAT'L INDUS. CONFERENCE BD., supra note 137. 
enthusiasm seemed conditional on an employer's supposedly unalienable "right to employ and discharge, the direction of the working forces . . . the management of the business ... reserved exclusively to the company."152 Workers and unions were not interested in this kind of work council, because without binding legal rights it was a sham: a dishonest alternative to collective bargaining. By 1925, 1,177,037 employees were covered by such work councils. This relatively low level suggests the initiatives were far more about staving off trade unions than managements implementing an obvious efficiency measure. ${ }^{153}$ Nevertheless, the NICB was intent on spreading the idea that its plans still embodied the true definition of "industrial democracy.". 154

After the Wall Street Crash, labor and capital reform also became a question of equality. President Roosevelt's Federal Reserve Chair from 1934, Marriner Stoddard Eccles, later wrote that the crash became a Depression because "hoarded funds" meant the "distribution of wealth" was not enough "to provide [people] with buying power equal to the amount of goods and services offered." 155 To change this, government support for unions became critical. The National Industrial Relations Act of 1933 guaranteed a charter of labor rights and would have promoted sectoral collective bargaining. It was struck down as "unconstitutional." 156 Instead, the reframed National Labor Relations Act of 1935 proclaimed its goal to remedy "inequality of bargaining power" between employees "and employers who are organized in the corporate or other forms." Although the new National Labor Relations Board (NLRB) focused only on building enterprise bargaining among local unions, the Act gave private sector workers federal rights to unionize, collectively bargain, and take-strike action. ${ }^{157}$ As the Act's sponsor, Senator Robert Wagner said, "democracy in industry must be based upon the same principles as democracy in government." 158

152. See generally NAT'L INDUS. CONFERENCE BD., REPORT NO. 21, WORKS COUNCIL MANUAL SUPPLEMENTAL RESEARCH (1920) (noting that union members should not be discriminated against).

153. NAT'L INDUS. CONFERENCE BD., REPORT No. 32, THE GROWTH OF WORKS COUNCILS IN THE United STATES: A STATISTICAL SUMMARY 5 (1925).

154. See generally NAT'L INDUS. CONFERENCE BD., REPORT NO. 50, EXPERIENCE WITH WORKS COUNCILS IN THE UNITED STATES (1922).

155. Marriner S. ECCles, Beckoning Frontiers: Public and Personal Recollections 75-77 (1951) ("[W]hile savings that are invested in new enterprises are beneficial not only to savers but also to the entire economy, savings that find no outlet and accumulate as idle or hoarded funds interrupt the flow of national income and result in a depression. As mass production has to be accompanied by mass consumption, mass consumption, in turn, implies a distribution of wealth-not of existing wealth, but of wealth as it is currently produced - to provide men with buying power equal to the amount of goods and services offered by the nation's economic machinery.").

156. Schechter Poultry Corp. v. United States, 295 U.S. 495 (1935).

157. National Labor Relations Act of $1935 \S \S 7-8$, 29 U.S.C. $\S \S 157-158$ (2012).

158. 79 Cong. Rec. 7571 (1935); see also N.Y. TIMES, Apr. 13, 2018, at 1. 
And now that people had something to organize for, they did. Even without widespread sectoral bargaining, union membership soared. So did employers' enthusiasm for company "unions." By 1935, 3,100 companies with 2.6 million workers had company "unions," and over two-thirds of them had arisen since 1933. ${ }^{159}$ In March 1934, Wagner had urged publicly that sham unions should be suppressed because otherwise employers would sit "on both sides of the table" or pull "the strings behind the spokesmen." " 160 The NLRA of $1935 \S 8(\mathrm{a})(2)$ made it unlawful to interfere with, or support, any labor organization. Under $\S 2(5)$, a labor organization meant anything where employees participated to deal with disputes or terms and conditions at work. ${ }^{161}$ In the first major case in 1939, NLRB $v$. Newport News Shipbuilding Co., ${ }^{162}$ the NLRB ordered disestablishment of a company "work council" at the Eastern Seaboard's largest docks, operating since 1927, so that an independent union could replace it. It resolved disputes and balloted employees, but the Supreme Court held it was unlawful because, like the NICB model, no decision of this "work council" could be implemented and the plan could not be amended without management approval. ${ }^{163}$ The law strictly outlawed sham participation, but $\S 8(\mathrm{a})(2)$ also lacked a positive model of work councils that unions could pursue.

How did the New Deal change social security? Reform followed a similar pattern of social action, court repression, and federal legislation.

159. Johanna Oreskovic, Capturing Volition Itself: Employee Involvement and the TEAM Act, 19 BeRKELEY J. EMP. \& LAB. L. 229, 241 (2014) (citing Hearings on S. 1958: Before the Committee on Education and Labor, 74th Cong. 40 (1935) (statement of Sen. Wagner, Chairman, Comm. Pub. Lands and Surveys), reprinted in 1 LEgISLATIVE HisTORY OF THE NATIONAL LABOR RELATIONS ACT, 1935, at $1416(1985))$.

160. Hearings on H.R. 6228 Before the H. Comm. on Labor, 74th Cong. 15 (1935); see also Robert F. Wagner, Company Unions: A Vast Industrial Issue, N.Y. TIMES, Mar. 11, 1934, at 1. Wagner, born in Germany, was acutely aware that in May 1933, Hitler's Nazi regime had violently seized the union movement, setting up the state controlled Deutsche Arbeitsfront. It was "probable that his own origins made Wagner particularly sensitive to the barbarities perpetrated by those who had assumed power in the land of his birth." J. JOSEPH HUTHMACHER, SENATOR ROBERT F. WAGNER AND THE RiSE OF URBAN LiberALiSM 268 (1968); see also Letter from Robert F. Wagner to J.B. Mayer (Jan. 16, 1934). Wagner was among the first to condemn Hitler's regime. Robert F. Wagner Papers, Wagner Speech File, Mar. 27, 1933; Robert F. Wagner Papers, International Affairs File, 1933-1939.

161. National Labor Relations Act of 1935, 29 U.S.C. $\S \S 152(5), 158(a)(2)$ (2012) (Section $152(5)$ states that it is an unfair labor practice "to dominate or interfere with the formation or administration of any labor organization or contribute financial or other support to it." Section 152(5) states that "a labor organization means any ... employee representation committee or plan, in which employees participate and which exists for the purpose, in whole or in part, of dealing with concerning grievances, labor disputes, wages, rates of pay, hours of employment, or conditions of work.").

162. NLRB v. Newport News Shipbuilding \& Dry Dock Co. 308 U.S. 241 (1939).

163. Id. at 250 (disestablishment of the plan was the "only effective way of wiping the slate clean and affording the employees an opportunity to start afresh in organizing for the adjustment of their relations with the employer."). 
First, California, Wyoming, New York, and Massachusetts had introduced pensions by 1930 , and almost half the states followed by $1933 .{ }^{164}$ Second, the Roosevelt administration passed the Railroad Retirement Act of 1934, with a compulsory contributory scheme for railway workers, vested in the U.S. Treasury and managed by a government board. The Supreme Court in Railroad Retirement Board v. Alton Railroad Co. struck it down. ${ }^{165}$ Echoing the reasoning in Buckstegge, Justice Owen Roberts, writing for the majority of the Court, stated that employers subsidizing employees of other companies was "an unnecessarily harsh and arbitrary imposition if the plan is to be what on its face it imports - a joint adventure with mutuality of obligation and benefit." 166

But third, the 1934 Act was only a prelude to the Social Security Act of 1935. The Supreme Court continued to strike down New Deal laws until on November 3, 1936, Roosevelt won reelection with $60.8 \%$ of the vote, carrying every state except Maine and Vermont. With Democrats prepared to pack the Court with new judges, ${ }^{167}$ Justice Roberts switched to support the New Deal. ${ }^{168}$ In Helvering v. Davis, a shareholder of Edison Electric Illuminating Co. brought a derivative claim to injunct the company from paying contributions under the Social Security Act, saying it exceeded the Federal government's power. ${ }^{169}$ Justice Benjamin Cardozo, now with a majority, explained that it was lawful for Congress to spend money for "general welfare," and Congress had broad discretion to determine what that meant.

Beyond the minimum provision of social security, how did workers get fair pensions? With more collective bargaining, more employers introduced workplace pensions, but many limited pensions to top officials while claiming the payments were tax deductible because it was for "some

164. Epstein, supra note 110, at 107-11; cf. DORA L. COSTA, THE EVOLUTION OF RETIREMENT: AN AMERICAN ECONOMIC HISTORY, 1800-1990, at 107-11 (1998). To paraphrase Justice Brandeis, it turned out that during the economic crisis many a "courageous state" were keen to "serve as a laboratory; and try novel social and economic experiments without risk to the rest of the country." New State Ice Co. v. Liebmann, 285 U.S. 262, 311 (1932) (Brandeis, J., dissenting).

165. Railroad Retirement Bd. v. Alton R.R. Co., 295 U.S. 330 (1935).

166. Id. at 357 (The government argued that it fulfilled the requirements of due process because pensions promoted efficiency due to their ability to improve morale and create loyalty to the company. The reply was apparently that the removal of the voluntary character of pensions necessarily "will eliminate all sense of loyalty and gratitude to the employer.").

167. President Roosevelt's Bill to Reorganize the Judicial Branch of the Government was known as the "court packing plan." S. 1392, 75th Cong. (1937); H.R. 4417, 75th Cong. (1937).

168. This succeeded first with the approval of Washington's minimum wage legislation in West Coast Hotel Co. v. Parrish, 300 U.S. 379 (1937). The NLRA of 1935 was approved in NLRB v. Jones \& Laughlin Steel Corp., 301 U.S. 1 (1937).

169. See generally Helvering v. Davis, 301 U.S. 619 (1937). 
or all employees." ${ }^{\prime 170}$ From the Stabilization Act of 1942 and Revenue Act of 1942 , tax exemptions could only be given if $70 \%$ of permanent employees were covered by a plan. During the war, wage restraints had been imposed, but pensions were exempt. ${ }^{171}$ Unions asked for pension contributions, instead of wage rises, through collective agreements. ${ }^{172}$ In Helvering, Justice Cardozo recorded that $75 \%$ people over 65 had been wholly or partly dependent on others in old age. ${ }^{173}$ Social security ended extreme dependence. Collective bargaining meant private sector pension coverage rose from $15 \%$ in 1940 to over $40 \%$ by $1960 .{ }^{174}$ And initially, unions bargained for plans where they controlled the contributions completely.

As World War Two drew to a close, American society had been transformed: it now had a modern system of social security, and meaningful labor rights were building a thriving middle class. People had enough money to save for retirement, and unions sought to manage workers' capital. Income inequality was decreasing as never before.

170. See Randolph E. Paul, The Background of the Revenue Act of 1937, 5 U. CHI. L. REV. 41, 77 (1937); George T. Altman, Pension Trusts for Key Men, TAX MAG., June 1937, at 324.

171. See Stabilization Act of 1942, Pub. L. No. 77-729, § 10, 56 Stat. 765, 768 (repealed 1956); Revenue Act of 1942, Pub. L. No. 77-753, § 165(a), 56 Stat. 798, 862-63 (codified as amended at 26 U.S.C. §401(a)) (allowing exclusion for temporary, seasonal or under-five-year workers, and prohibiting discrimination in favor of executives, except insofar as benefits could be proportional to pay); Arthur H. Kent, The Revenue Act of 1942, 43 Colum. L. REV. 1 (1943); Leon L. Rice Jr., Employee Trusts under the Revenue Act of 1942, TAX MAG., Dec. 1942, at 721. (1940).

172. See generally Editor, Legal Status of Private Industrial Plans, 53 HARV. L. REV. 1375

173. MARJORIE SHEARON ET AL., ECONOMIC INSECURITY IN OLD AgE: SOCIAL AND ECONOMIC FACTORS CONTRIBUTING TO OLD-AGE DEPENDENCY 15 (1937).

174. Alicia H. Munnell \& Steven A. Sass, Social Security and the Stock Market: HOW THE PURSUIT OF MARKET MAGIC SHAPES THE SYSTEM 32 (2006) (depicting a graph showing a high of $47 \%$ in 1982 and declining to an unsteady level around $43 \%$ by 2004$)$. 
Figure 2

\section{US union membership and income inequality, 1900-2012}

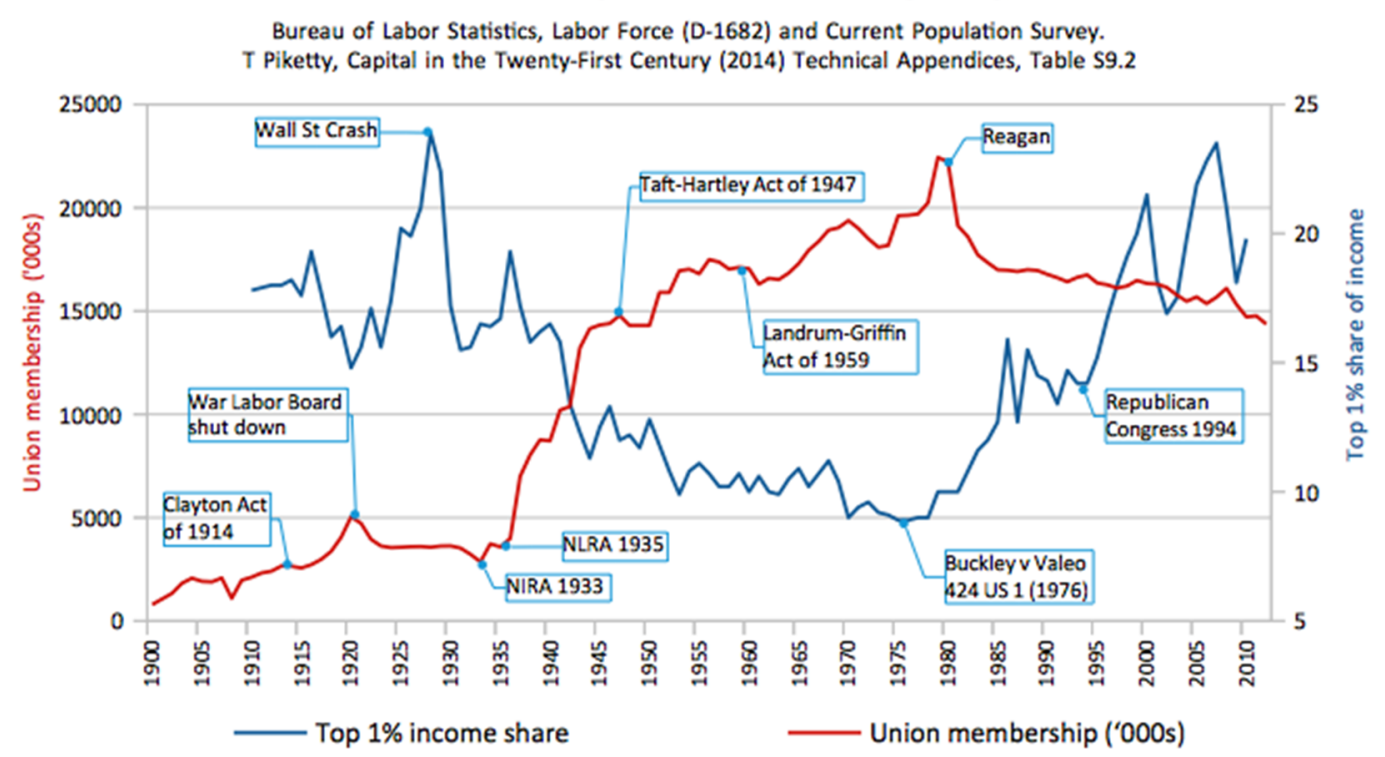

Labor rights and social security were central to what Roosevelt called in 1944 a "Second Bill of Rights," designed to achieve "new goals of human happiness and well-being." "175 But there was one notable absence: there was no settled view yet on the constitution of economic relations. Collective bargaining strength was growing, but who appointed the company boards unions bargained with? Pensions funds were building, but who would control the assets? Sham company unions were banned, but what could a legitimate work council look like? Ironically, in 1946 in occupied Germany, the United States Military Government passed Control Council Law No. 22, which set out a model work council that unions could bargain for. ${ }^{176}$ German workers and unions had the right to establish work councils with rights to enforce collective agreements, investigate grievances, participate in setting up social insurance and social welfare, and collectively agree on any further functions for work councils, reserved from management prerogative. ${ }^{177}$ The United States helped win the war for peace, democracy, and social justice abroad, but it was not yet there at home.

\footnotetext{
176. Control Council Law No. 22 Works Councils, Apr. 10, 1946, OfFiCial GaZETTE OF THE CONTROL COUNCIL FOR GERMANY 1945-1946, at 133-36 (1946), LSE Archives 43 (R498).

177. Id. arts. IV-V.
} 1948).

175. See G.A. Res. 217 (III) A, arts. 20-26, Universal Declaration of Human Rights (Dec. 10, 


\section{Democracy in America, Almost: 1946 to 1980}

Labor's position after World War Two was one of unprecedented strength, yet it was vulnerable. In the period up to 1980, labor became increasingly aware of, and organized to use, its power in pension savings to democratize corporate governance. This culminated in an astonishing, concerted effort to win representation on company boards of directors. At the same time, the interests behind corporate boardrooms and Wall Street consolidated their opposition and used every instrument of the state - the legislature, executive, and courts - to halt labor's advance.

By 1946, union density had climbed to $35.5 \%$ of non-agricultural workers, and labor was determined to secure an increase in wages. Unions went on strike: one of the largest waves in American history. ${ }^{178}$ Employers accused unions of having an "unfair" advantage by using pensions to pay strikers. They argued employers should have no duty to bargain over pensions at all, ${ }^{179}$ and shareholders brought derivative actions arguing any payments to union pensions were ultra vires. ${ }^{180}$ In Congress, Senator Robert Taft proposed a prohibition on employees' involvement in pensions. ${ }^{181}$ This mirrored the position of the U.S. Chamber of Commerce that "the primary responsibility for... old age must rest with the individual." ${ }^{182} \mathrm{He}$ singled out the United Mine Workers pension fund, ${ }^{183}$ where the union leader, John Lewis, demanded a solely union administered fund from the government. ${ }^{184}$ The miners' dispute itself was resolved by the federal government getting an agreement to jointly administer the fund.

178. See JaCk Metzgar, The 1945-1946 Strike Wave, in The ENCyClOPEDIA OF STRIKES IN AMERICAN HISTORY 216-25 (A. Brenner et al. eds., 2009) (explaining the standard demand became an $18.5 \%$ pay raise).

179. Inland Steel Co. v. Nat'l Labor Relations Bd., 170 F.2d 247 (7th Cir. 1948) (holding that pensions were a mandatory subject of collective bargaining), cert. denied, 336 U.S. 960 (1949).

180. F. Hodge O’Neal, Stockholder Attacks on Corporate Pension Systems, 2 VAND. L. ReV. 351 (1949)

181. 93 CONG. REC. 4892 (1947); see also H.R. REP. NO. 80-245, at 29-30 (1947), reprinted in 1 NLRB, Legislative History OF the Labor MANagement Relations ACt OF 1947, at 309 (1948); House Set to Compromise on Labor Bill in Order to Obtain Measure on Which Veto Could Be Beaten, WALL ST. J., May 10, 1947, at 3.

182. Conference on Emp. Pension Plans, Conference Minutes (July 9-10, 1947) (unpublished minutes) (on file with USCOC Collection, Series 3, Box 6, Employee Pension Plans folder).

183. R Blodgett, Union Pension Fund Asset Management, in ABUSE ON WALl Street 320, 321 (1980).

184. Louis Stark, New Strike Looms, Coal Official Says, N.Y. TimES, Feb. 12, 1947, at 5 (Quoting the hostile view of Forney Johnston of the National Coal Association, that the Union of Mine Worker proposed funds "are now on the agenda of every central union in a program of sweeping encroachment on the earnings and on the functions of ownership and management, with no limitation whatever except the conscience of the union dynasty."); see also United States v. United Mine Workers of Am., 330 U.S. 258 (1947). 
In the November 1946 election, Republicans won a majority in Congress and the new Taft-Hartley Labor Management Relations Act 1947 was passed to reduce labor power. It created an express right for employers to proselytize against a union, created unfair labor practices for unions, reinstated the prohibition on secondary action, and prohibited the closed shop: unions could charge non-members fees for their services, unless state laws stopped it. ${ }^{185}$ For pensions, its central change was $\S 302(\mathrm{c})(5)(\mathrm{B})$. While it did not affect union pension funds that were already established, ${ }^{186}$ employers could pay no money into a new union fund unless the board was managed jointly, with a neutral umpire or a court determining disputes in case of deadlock. ${ }^{187}$ While Carnegie's TIAA was designed with rights to minimum labor voice in pensions, Taft-Hartley guaranteed a minimum voice for corporate boardrooms. President Harry Truman vetoed the Act, but enough Democrats supported it that it became law.

While the Taft-Hartley Act suppressed union governance of workers' capital, more and more plans were collectively agreed to under the jointmanagement model, ironically named Taft-Hartley plans. ${ }^{188}$ By 1960, in addition to single-employer pensions, Taft-Hartley multi-employer plans covered 3.3 million workers, ${ }^{189}$ rising to 9.7 million workers in $1988 .{ }^{190}$ As Taft had known well, ${ }^{191}$ this money could be invested in shares. Employers were keen to preempt union control if they could. In 1950, in the so-called "Treaty of Detroit," 192 which was flaunted as a victory for both sides, General Motors initiated a sole-employer pension as part of a five year collective agreement. ${ }^{193}$ Managers were instructed to be inactive in corporate governance, and the treaty confined investment to a maximum

185. Labor Management Relations Act of 1947 §302(c)(5)(B), 29 U.S.C. § 186 (2012).

186. Gerald P. Cunningham, The Employee Retirement Income Security Act of 1974 and Union Influence in Pension Fund Investment Decisions, 12 FORDHAM URB. L.J. 151, 153 (1983).

187. Labor Management Relations Act of 1947 §302(c)(5)(B), 29 U.S.C. § 186 (2012). (2002).

188. Robert Cook, The Case for Joint Trusteeship of Pension Plans, 6 J. LAB. \& SoC’Y 26

189. H. Robert Bartell \& Elizabeth T. Simpson, Pension Funds of Multiemployer INDUSTRIAL GROUPS, UNIONS, AND NONPROFIT ORGANIZATIONS 105 (1968).

190. 135 CONG. REC. 5984-6005, 6233 (1989) (citing a study by the ME Segal consulting firm).

191. Jeremy Rifkin \& RANDy Barber, The North Will Rise Again: Pensions, Politics AND POWER IN THE 1980S, at 101 (1978) ("Senator Claude Pepper of Florida . . . suggest[ed] that Taft and his business friends, when they fretted over possible union abuses of the funds, were really fretting over the possibility that they might lose control of the potential pool of capital that pension funds represented. Pepper was right, but despite the fact, or probably because of it, the vote went against labor.").

192. Daniel Bell, The Treaty of Detroit, FORTUNE, July 1950, at 53.

193. Fredrick H. Harbison, The General Motors-United Auto Workers Agreement of 1950, 58 J. POL. ECON. 397 (1950). 
of $0.75 \%$ in any company's stock. ${ }^{194}$ By contrast, in 1952 the AFL-CIO released a ten-point bargaining agenda that included joint-investment boards. ${ }^{195}$ The Teachers Insurance and Annuity Association was also extended to buy into shares, with the College Retirement Equity Fund: this made TIAA-CREF. ${ }^{196}$ These steps were still rare: only in 1967 was California's Public Employee Retirement Scheme, CalPERS, first able to invest $25 \%$ of its assets in shares. Only in 1984 was the limit removed. ${ }^{197}$

The spirit of the 1950s was unfavorable to labor. Along with Senator McCarthy's "investigations" aiming to conflate unions with Soviet dictatorship, a fund manager named Louis Kelso was popularizing stock ownership, especially among employees, as the only way to have voice in the economy. ${ }^{198}$ His motivation, which caught Republican attention, was to ward off socialism by making all workers small capitalists without any toleration of collective voice. ${ }^{199}$ This was not Carnegie's pre-TIAA worker-shareholder vision, nor was there any goal to ensure worker voice. Kelso believed in the right to manage. Even on the Democratic side of politics, Robert F. Kennedy's search for the so-called "Enemy Within" culminated in an ever-growing set of burdens on union governance in the Landrum-Griffin Act of $1959 .{ }^{200}$ With states limiting unions under TaftHartley, even more than raw membership, ${ }^{201}$ union density faltered.

194. Peter F. Drucker, The UnSEEn Revolution: How Pension Fund Socialism CAME to AMERICA 7 (1976); PAul HARBReCht, Pension FundS AND ECONOMIC POWER 8 (1959).

195. Teresa Ghilarducci, Labor's Capital: The ECONOMics and Politics of Private PENSIONS 116 (1992).

196. GREENOUGH, supra note 97, at 360-62. In 1988, to register a new money market fund with the SEC, TIAA-CREF risked losing charitable status, although it was previously exempt under 26 U.S.C. $\S 501(c)(3)$. Instead, CREF trustees were wholly elected by policyholders, according with the Investment Company Act 1940 § 16, 15 U.S.C. § 80a-16 (2012).

197. See generally Christopher J. CASTANEdA, Dedication, Vision, HEART: THE CALPERS STORY (2007).

198. KELSO \& ADLER, supra note 14, at 202-04 ("Equity-sharing plans should not be built around the concept of retirement .... [It should enable] the worker gradually to shift, over the period of his employment, from absolute dependence on toil as the source of his income to dependence, in a substantial degree, on his ownership of a capital interest.").

199. Louis Kelso \& Patrica Hetter, How to Turn Eighty Million Workers into CAPITALISTS ON BORROWED MONEY (1967).

200. Labor Management Reporting and Disclosure Act of 1959, 29 U.S.C. $\$ 401$ (2012); see Ewan McGaughey, Democracy or Oligarchy? Models of Union Governance in the UK, Germany and US 36-38 (King's Coll. London Law Sch., Research Paper No. 2017-35, 2017).

201. N.B. The United States is unique compared to other countries in that it is experiencing sustained, rapid population growth. There were 76 million people in 1900, 123 million by 1930, 151 million by 1950, 203 million by 1970, 248 million by 1990, and over 328 million today. 
Figure 3

\section{US union density and income inequality, 1930-2012}

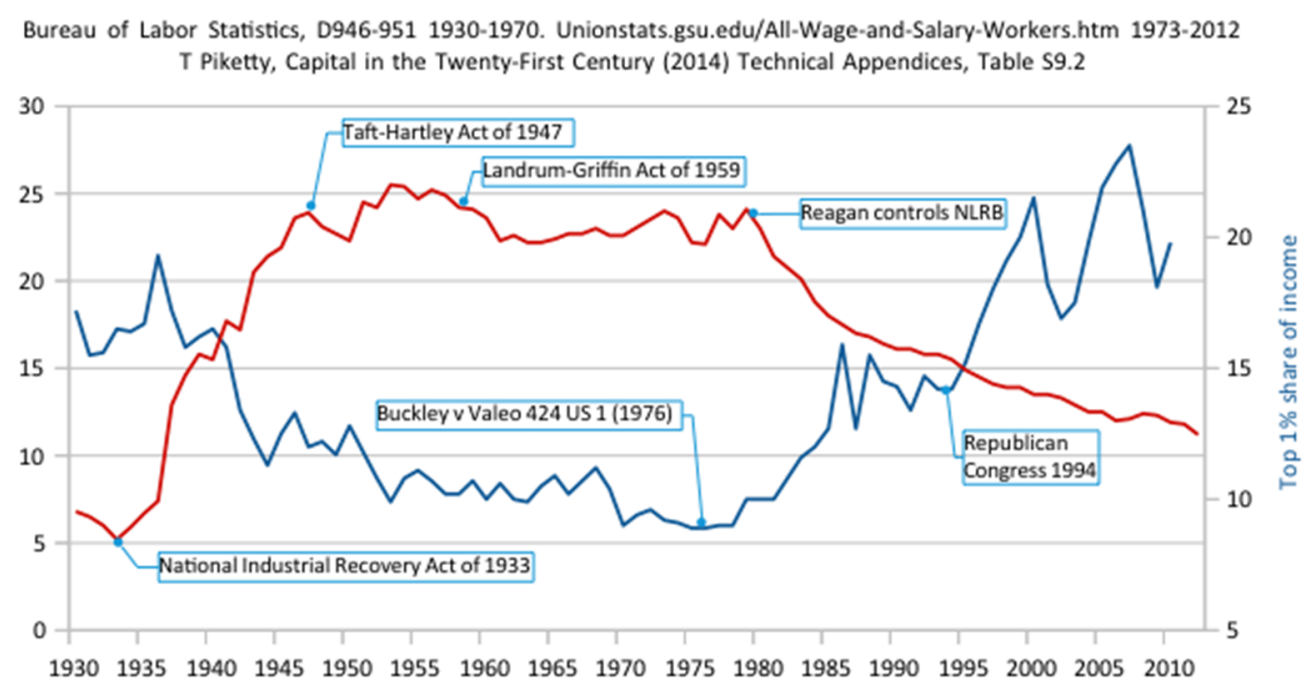

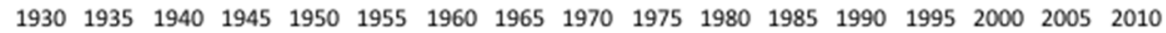

Top $1 \%$ income share Union density

Nevertheless, by the 1960s labor rights were strong enough to create "a rising tide" that "lifts all boats." "In 1965, A.A. Berle believed a peaceful "revolution" was still in motion, as the old forces of private property were infused with a constitution of economic and social rights. Workers saving for pensions, encouraged by tax reform, meant a growing stake for everyone in economic growth. ${ }^{203}$ In 1968, Paul Blumberg went further, arguing in Industrial Democracy: the Sociology of Participation for the economic and scientific case to expand voice at work. ${ }^{204} \mathrm{He}$ argued that in the leading management case study, the Hawthorne experiments of Elton Mayo, the data showed productivity rose when workers were given genuine control over their working patterns, were no longer subjected to authoritarian managers, and were treated with dignity. ${ }^{205}$ This became known as the "participation hypothesis," meaning that "significant changes in human behavior can be brought about rapidly only if the

202. Ted Sorenson, Counselor: A Life At the Edge Of History 227 (2008) (John F. Kennedy's speechwriter attributes the phrase to the regional chamber of commerce, the New England Council.).

203. Adolf A. Berle, Property, Production and Revolution, 65 Colum. L. Rev. 1 (1965).

204. Paul Blumberg, Industrial Democracy: The Sociology of Participation chs. 2 3 (1968).

205. Compare id. at 25, with Elton Mayo, TEAmwork and Labor TURNOver IN THE AIRCRAFT INDUSTRY OF SOUTHERN CALIFORNIA (1944). 
persons who are expected to change participate in deciding what the change shall be and how it shall be made."206

The benefits of labor participation were not completely ignored in government. While sham company unions were unlawful, there had been real success with "Scanlon plans" developed in 1938 by Ohio union leader Joseph Scanlon: workers made suggestions for production and administration in return for guaranteed bonuses if suggestions worked. ${ }^{207}$ The President's National Commission on Productivity and Work Quality in 1972 sought to promote productivity, including drawing on joint unionmanagement committees. ${ }^{208}$ Some unions were wary of participation either with or in management, ${ }^{209}$ a view that some managerial interests appeared keen to encourage. But many workers and unions were not shy because they could see the right to select directors operating effectively in other countries. ${ }^{210}$

The early 1970s unlocked a wave of experiments for workers on boards, both through collective bargaining and voice in shares. In 1971, the first proxy proposal was made at the General Motors annual meeting for employee representation, followed by similar proposals the following year at Ford, and the Illinois retailer Jewel. ${ }^{211}$ Also in 1972, the pilots of United Airlines used the shares they held collectively to propose board representation at the 1972 stockholder meeting. They won $5 \%$ of the vote. $^{212}$ At AT\&T, shareholders proposed employees be included on the board to "provide a continuing flow of information to management" and "avoid periodic labor disruptions which place financial hardships on

206. H.A. Simon, Recent Advances in Organization Theory, in RESEARCH FronTIERS IN POLITICS AND GOVERNMENT 23, 28-29 (1955).

207. ROBERT J. KÜHNE, CO-DETERMINATION IN BUSINESS: WORKERS' REPRESENTATIVES IN THE BOARDROOM 113-14 (1980) (By 1945, around 3,200 companies had joint production committees, but in 1948 most had ended. Interest revived haphazardly afterward.). See generally Gilbert K. Krulee, The Scanlon Plan: Co-Operation Through Participation, 28 J. Bus. 100 (1955).

208. E.g., NAT'L COMM'N ON PRODUCTIVITY, ANNUAL Report No. 1, at 17 (1972) (United Steelworkers of America AFL-CIO, in its 1971 collective agreement, required "joint union-industry committees on productivity at the plant level."); see also NAT'L COMM'N ON PRODUCTIVITY, ANNUAL REPORT NO. 4, at 21 (1975) (making clear these "committees are not a substitute for nor an alternative to collective bargaining").

209. Robert Dahl, Power to the Workers?, N.Y. Rev. OF Books, Nov. 19, 1970, at 9 ("[M]any employees of a particular firm might not wish to participate in governing . . . workers and trade unions may be the greatest barriers at present to any profound reconstruction of economic enterprise in this country .... Along with the officialdom of the trade union movement, workers are deeply ingrained with the old private property view of economic enterprise ... affluent workers ... tend to be consumption-oriented, acquisitive, privatistic, and family-centered.").

210. E.g., McGaughey, supra note 16.

211. Phillip I. Blumberg et al., Corporate Social Responsibility Panel: The Constituencies of the Corporation and the Role of the Institutional Investors, 28 BUS. LAW. 177, 179 (1973).

212. Brian Hamer, Serving Two Masters: Union Representation on Corporate Boards of Directors, 81 COLUM. L. REV. 639, 640 (1981). 
employees and impose losses on the company and shareowners." ${ }^{213}$ In 1973, workers at the small Providence and Worcester Railroad succeeded in getting representation by collective bargaining, which the Wall Street Journal described as a "precedent shattering labor agreement." 214 The United Rubber Workers also proposed to the General Tire and Rubber Company that a union member be appointed to the board, but they were turned down. ${ }^{215}$

These developments in worker representation plainly troubled the Nixon administration. In 1974, the Securities and Exchange Commission, using its power to regulate shareholders soliciting support for proposals, ${ }^{216}$ issued a letter to AT\&T that management could exclude proposals for worker directors to be placed on boards. ${ }^{217}$ This was ostensibly because New York law, where AT\&T was incorporated, gave the right to elect directors to shareholders. It ignored that a simple bylaw amendment could create classes of shareholders, or shareholders could agree to use their votes to guarantee worker representatives. It was far from clear that agreement upon shutting down experiment was widespread: the Republican Senator for New York, Jacob K. Javits, said that "an effort to open up corporate board room opportunities to workers would improve workers' understanding of management as well as exposing management to workers' ideas." 218 Unions persisted. In 1976, the Teamsters union proposed that two union representatives be appointed to the board of the brewing giant, Anheuser-Busch. ${ }^{219}$ Similarly, the International Federation of Professional and Technical Engineers proposed at AT\&T's annual meeting that a union representative be put on the board, but the proposal won just $3.3 \%$ of votes cast.

The SEC and management opposition played into uncertainty within the labor movement. While many unions themselves were strongly in favor of board representation, the AFL-CIO, at a time of considerable pressure, was not. Thomas Donahue (who became Secretary-Treasurer

213. Jerry W. Markham, Restrictions on Shared Decision-Making Authority in American Business, 11 CAL. W. L. REV. 217, 245-46 (1975).

214. Davison Douglas, Labor Unions in the Boardroom: An Antitrust Dilemma, 92 YALE L.J. 106, 106 n.1 (1982).

215. Union Asks Seat on Board, N.Y. TIMES, Mar. 27, 1973, at 31.

216. Securities and Exchange Act of 1934 § 14(a), 15 U.S.C. $§ 781$ (1964); 17 C.F.R. $§ 240.14-$ $8(\mathrm{c})(l)(1970)$ (A company can omit to consider a proposal if "the proposal as submitted is, under the law of the issuer's domicile, not a proper subject for action by security holders.").

217. American Telephone \& Telegraph Company, Fed. Sec. L. Rep. (CCH) 9 79,658 (1974). In 1974 , there were 363 work days lost per 1,000 workers to strikes in the United States, but only 3 per 1,000 workers in Germany. Bennet Abramowitz, Broadening the Board: Labor Participation in Corporate Governance, 34 Sw. L.J. 963, 984 (1980).

218. KüHNE, supra note 207 , at 105.

219. Lassus, What the Teamsters Really Wanted, BEVERAGE WORLD, June 1976, at 34 (cited by Douglas, supra note 213, at 106 n.1). 
from 1979 to 1995, and briefly President) said in 1976 that because "American unions have won equality at the bargaining table, we have not sought it in corporate boardrooms." He did not want to be "the junior partner in success and the senior partner in failure" or "blur the distinction between management and labor."220

But unions that bargained directly with management pressed on. In 1976, the United Auto Workers (UAW) declared that they sought representation on the board of Chrysler. The proposal was rejected, ${ }^{221}$ but then in 1979, as Chrysler drifted into severe financial problems, the board conceded, and a worker director stepped on board. ${ }^{222}$ Chrysler denied "that it intended to establish any principle of labor representation." But Douglas Fraser, UAW President and the new director, said this was "nonsense" and just "to protect their flanks." 223 As Fraser declared before his election by shareholders, arranged by the board, "it isn't enough for a union to argue about plant closings or layoffs after the decision has been made."224

How did corporate boardrooms and Wall Street react to labor's growing assertiveness? First, in 1971, Lewis Powell wrote a memo for the U.S. Chamber of Commerce urging concerted action in public education, journalism, and for the courts to stop the "[a]ttack on [the] American Free Enterprise System." ${ }^{225} \mathrm{He}$ urged business to "press vigorously in all political arenas for support of the enterprise system," learning lessons "from organized labor in this respect" because the "American business executive," Powell lamented, "is truly the "forgotten man." It was true that in 1969 the Delaware General Corporation Law § 141(h) was amended, virtually unnoticed, to enable directors to set their own pay. ${ }^{226}$ Before this, the standard rule was that pay was set in bylaws or by shareholder vote. This triggered an exponential curve in the chart below, Figure 4. But far more profound and damaging in the long-term was Nixon's placement of Powell on the Supreme Court. In the first case after Justice William O. Douglas left the bench, Buckley v. Valeo, it was

220. Eileen Appelbaum \& Larry W. Hunter, Union Participation in Strategic Decisions of Corporations 267 (Nat'1 Bureau of Econ. Research, Working Paper No. 9,590, 2003).

221. Craig R. Whitney, Auto Union Seeks Directors' Seats, N.Y. TIMES, May 13, 1976, at 51; $c f$. JOHN FURLONG, LABOR IN THE BOARDROOM (1977).

222. John D. Blackburn, Worker Participation on Corporate Directorates: Is America Ready for Industrial Democracy?, 18 Hous. L. REV. 349, 352 (1981).

223. UAW's Fraser to Speak Out for Labor, Public, in Role as Director of Chrysler, WaLl ST. J., Oct. 29, 1979, at 6.

224. WaLl St. J., May 14, 1980, at 6.

225. Memorandum from Lewis F. Powell Jr. to Eugene B. Syndor Jr., Chairman of the Educ. Comm. of the U.S. Chamber of Commerce, Attack on American Free Enterprise System (Aug. 23, 1971).

226. S. Samuel Arsht \& William K. Stapleton, Delaware General Corporation Law: 1969, 25 BUS. LAW. 287 (1969). 
decided, over powerful dissent, that candidates for political office could spend unlimited amounts of money in election campaigns: it was "unconstitutional" under the First Amendment to try and stop them. ${ }^{227}$ This was soon followed by First National Bank of Boston v. Bellotti, where Justice Powell held that state legislation could not restrict expenditure by corporations during a ballot. ${ }^{228}$ This must be seen as the start of an exponential rise in inequality, as the American social and political system was ground to a halt by money.

Figure 4

\section{US inequality and executive pay ratios}

Sources: Piketty (2014), Davis and Mishel (2014), Lewellen (1968)

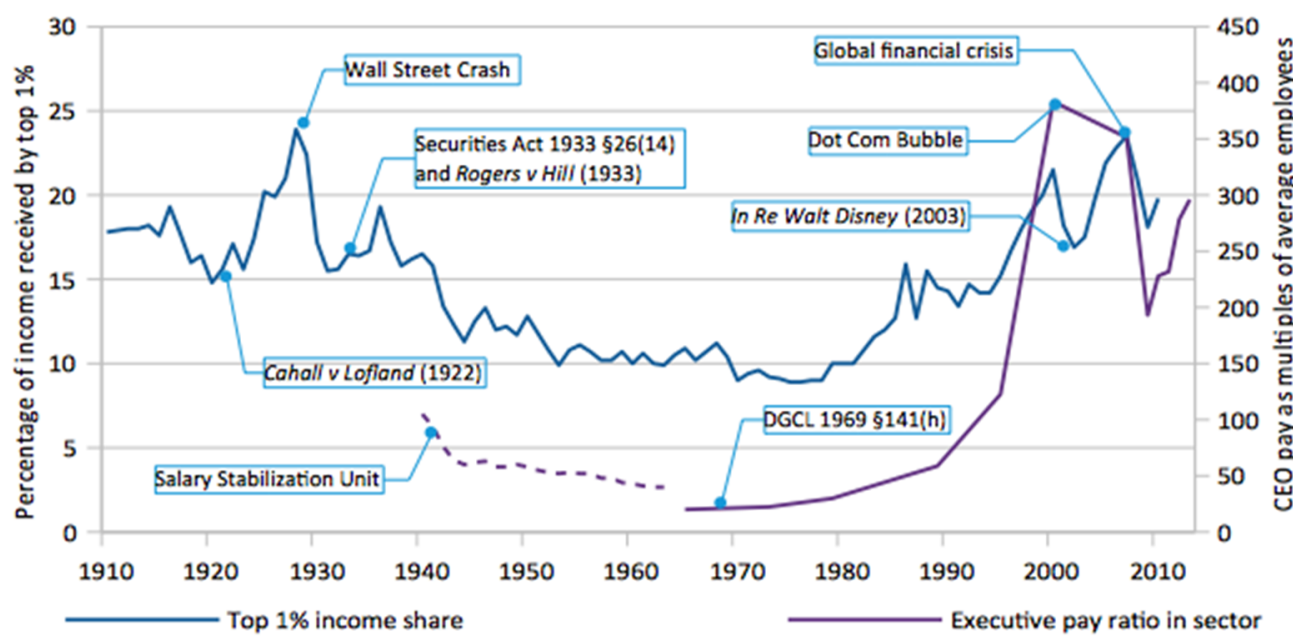

- - - - - - Executive pay ratio to manufacturing employees

227. Buckley v. Valeo, 424 U.S. 1 (1976). In this case, the Supreme Court struck down parts of the Federal Election Campaign Act of 1971. In his dissent, Justice White explained,

Congress was plainly of the view that these expenditures also have corruptive potential; but the Court strikes down the provision, strangely enough claiming more insight as to what may improperly influence candidates than is possessed by the majority of Congress that passed this bill and the President who signed it.... Without limits on total expenditures, campaign costs will inevitably and endlessly escalate .... By limiting the importance of personal wealth, [\$] 608(a) helps to assure that only individuals with a modicum of support from others will be viable candidates. This in turn would tend to discourage any notion that the outcome of elections is primarily a function of money.

$I d$. at 261-66 (White, J., concurring in part and dissenting in part).

228. First Nat'l Bank Bos. v. Bellotti, 435 U.S. 765 (1978). Justice White wrote,

Corporations are artificial entities created by law for the purpose of furthering certain economic goals ... the special status of corporations has placed them in a position to control vast amounts of economic power which may, if not regulated, dominate not only the economy but also the very heart of our democracy, the electoral process.

Id. at 809 (White, Brennan, and Marshal, JJ., dissenting); see also J. Skelly Wright, Money and the Pollution of Politics: Is the First Amendment an Obstacle to Political Equality?, 82 COLUM. L. REV. 609 (1982). 
Second, the structure of capital was gradually changed. In 1965, a Committee on Corporate Pension Funds had recommended federal rights against pensions being withdrawn by employers, so that they "vested," and standards for funding. ${ }^{229}$ In 1972, the NBC documentary Pensions: The Broken Promise publicized the extent of the problems. ${ }^{230}$ If workers moved jobs, they had no right to take their pensions with them. Employers might also promise a pension but set aside no money. This led to the Employee Retirement Income Security Act (ERISA) of 1974, requiring that money vested after one year's work, and that defined benefit (DB) schemes had minimum funding, guaranteed by the Pension Benefit Guaranty Corporation. ${ }^{231}$

Positive though ERISA was, it also influenced governance choices. A plan had to be in a written instrument, and assets had to be held by trustees which could include a company's own officers or employees, despite the possible conflicts of interest. ${ }^{232}$ Moreover, ERISA $\S 402(d)(1)$ created immunity for trustees in negligence cases (including duties to diversify) if they outsourced or "delegated" to an external manager, and $\S 404(c)(1)$ created immunity for the employer (the plan "sponsor") if beneficiaries exercised any minimal control over the plan's assets. At the time, only a handful of public pensions-for California, ${ }^{233}$ Connecticut, and Nebraska state employees, as well as Ohio teachers-enabled pension

229. President's Comm. on Corporate Pension Funds and Other Private Ret. and Welfare Programs, Public Policy and Private Pension Programs (1965); see Arthur C. O'Meara, Public Policy and Private Pension Programs, 21 Bus. Law. 971 (1966); $c$. House Comm. On InTERSTATe \& FOREIGN COMMERCE, REPORT OF THE SEC ON THE PUBLIC POLICY IMPLICATIONS OF INVESTMENT COMPANY GROWTH, H.R. REP. NO. 89-2337 (2d Sess. 1966).

230. Pensions: The Broken Promise (NBC News 1972). The documentary won a Peabody Award and sufficiently outraged the Richard Nixon government and lead the Nixon administration to bring an action, through the Federal Communications Commission, for breaching the then "fairness doctrine" that programming had to be duly impartial. After the Nixon-controlled FCC found that NBC was in breach, the Federal Court of Appeals overturned the ruling to find no breach in Nat'l Broad. Co. v. FCC, 516 F.2d 1101 (D.C. Cir. 1974). The fairness doctrine was later abolished by the Reagan administration, so that broadcasting does not need to give any semblance of fairness, due impartiality, or accuracy. Equivalent laws persist for all television in the United Kingdom under the Communications Act, 2003, c.21, § 319 (Eng.), and in Germany, see Rundfunkstaatsvertrag [RSTV] [Interstate Broadcasting Agreement], July 31, 1991, § 11. Internet regulation has not yet caught up.

231. 29 U.S.C. $\S 1081-1102$ (1980).

232. Employee Retirement Income Security Act of $1974 \S \S 402(a), 403(a), 408(c)(3), 29$ U.S.C. $\S$ 1102(a), 1103(a), 1108(c)(3) (2012) [hereinafter ERISA]; see Mark J. Roe, The Modern Corporation and Private Pensions, 41 UCLA L. Rev. 75, 91 (1993) ("[C]onflicts that benefit managers are tolerated.").

233. See Castaneda, supra note 197 (Section 20100-3 of the California Government Code (1991), now found in $\S 20090$ (2011), requires seven members appointed by the employer (i.e., the government), but six elected by beneficiaries, from 2010.). 
beneficiaries to elect their trustees. ${ }^{234}$ ERISA did nothing to empower the ultimate investors of capital: it encouraged the reverse.

The incentives for pension trustees and employers to outsource pension management enabled asset managers to take shareholder voting rights on other people's money. Tax incentives drove this further. First, the Self-Employed Individuals Tax Retirement Act of 1962 originally allowed self-employed workers to establish tax deferred saving accounts, called Keogh plans. Second, ERISA extended this right to defer tax to a maximum of $\$ 2,000$ a year in Individual Retirement Accounts (IRAs) to everyone, including workers who already had employer, union, government or Keogh pensions plans. IRAs were often held by banks. Tax exemptions were created for employers who put worker retirement money or savings into stock ownership schemes. ${ }^{235}$ Third, people still wanted to put more funds in tax-deferred accounts, so the Internal Revenue Code of $1978 \S 401(\mathrm{k})$ was introduced. Employers found these "401(k)" plans convenient. They could send off their staff details and fund "choices" to be organized by an investment manager. ${ }^{236}$ If the fund's management was outsourced, trustees had no liability. If beneficiaries had some choice of plan, employers had no liability.

This series of changes (the incentives to outsource investment management and the easy option of IRAs) laid the groundwork for an assault on workers' pensions in the 1980s. In 1976, the management theorist Peter Drucker argued that because workers' pensions made up $25 \%$ of equity capital, and "by 1985 (probably sooner), they will own at least 50-if not 60 per cent — of equity capital. ${ }^{237}$ But the stark reality was that workers lacked any meaningful voice over their money. As Rifkin and Barber argued in 1978, banks and asset managers exercised "direct control" and "have sole voting rights for the stock they purchase with pension-fund assets." ${ }^{238}$ For example, Chase Manhattan managed a \$423 million pension for the tire company Firestone while at the same time the bank trust held 950,000 shares in Firestone. ${ }^{239}$ Also, the former Chase president sat on Firestone's board. Rifkin and Barber hoped that an upcoming case, Daniel v. Teamsters, might see the Supreme Court

234. Louis M. Kohlmeier, State and Local Pension Fund Asset Management, in ABUSE ON WALL STREET, supra note 182, at 278 (1980). Ohio's system of representation began in 1973. The Wisconsin State Teachers Retirement System, unusually, had a wholly employee elected board, although a separate State of Wisconsin Investment Board managed investments, and were appointed. 235. ERISA $\S 407(d)(6) ; 26$ U.S.C. $\$ 4975(\mathrm{e})(7)$.

236. Jennifer S. Taub, Able but Not Willing: The Failure of Mutual Fund Advisers to Advocate for Shareholders' Rights, 34 J. CORP. L. 843, 876 (2009).

237. Peter F. Drucker, The Unseen Revolution: How Pension Fund Socialism Came to AMERICA 1 (1976).

238. RIFKIN \& BARBER, supra note 191, at 114.

239. Id. at 116. 
approve the view that every beneficiary had "the right to exercise control over some $\$ 400$ billion in pension assets." ${ }^{240}$ Perhaps not surprisingly, the Supreme Court did not oblige. ${ }^{241}$

Third, it was clear that a number of business leaders, however irrationally, viewed workers on boards "with horror."242 In 1976, Michael Jensen and Bill Meckling gave that horror a theoretical framework by arguing that efficient enterprise came about through the reduction of "agency costs" in the "nexus of contracts" that made up a corporation. ${ }^{243}$ The idea that a corporation was a bundle of contracts was not new. ${ }^{244}$ Emboldened by its absence of empirical foundation, the theory's critical feature was a total rejection of bargaining power as a relevant factor in explaining who got voice in corporate governance. In 1979, Jensen and Meckling warned that if workers entered board rooms, or legislation was introduced like in West Germany, the economy would grind to a halt as it had in Marshall Tito's Yugoslavia. ${ }^{245}$ This echoed the Business Roundtable's view: workers on boards were "inconsistent with U.S. traditions and style of management-labor relationships at arm's length." The notion that workers might have any vote in corporate governance was rejected. ${ }^{246}$

\section{Ownership Society, Enron Economy: 1980 to 2018}

In many ways, the evolution of labor's voice in corporate governance since 1980 played out the consequences of Buckley v. Valeo: labor law "ossified" and asset managers, not the real investors of capital, took over votes in the economy because the capacity for progressive legislation was

240. Id. at 135 .

241. Daniel v. Int'1 Bhd. Of Teamsters, 561 F.2d 1223, 1241-42 (7th Cir. 1977) ("Because employee pension plans are now the major, if not sole, form of investment for most American workers to provide for their old age and because of the now crucial role that such plans play in today's capital markets, they are just the sort of investment vehicle that the securities acts were passed to regulate."), rev'd, 439 U.S. 551 (1979).

242. Richard M. Steuer, Employee Representation on the Board: Industrial Democracy or Interlocking Directorate, 16 COLUM. J. TRANSNAT'L L. 255, 255 (1977).

243. Michael C. Jensen \& William H. Meckling, Theory of the Firm: Managerial Behavior, Agency Costs and Ownership Structure, 3 J. FIN. ECON. 305, 311 (1976).

244. Friedrich Kessler, Wirtschaftsführertum und Vertragsethik im Neuen Aktienrecht, 83 U. PA. L. REV. 393 (1935) (reviewing Johannes Zahn's book the German Aktiengesetz 1937); see Ewan McGaughey, Ideals of the Corporation and the Nexus of Contracts, 78 MoD. L. REV. 1057 (2015).

245. Michael C. Jensen \& William H. Meckling, Rights and Production Functions: An Application to Labor-Managed Firms and Codetermination, 52 J. BuS. 468, 469-506 (1979).

246. Business Roundtable, The Role and Composition of the Board of Directors of the Large Publicly Owned Corporation, 33 Bus. LAw. 2083, 2107 (1978). The term "arms length" is probably a reference to the U.S. Supreme Court decision in Pepper v. Litton, 308 U.S. 295, 306-07 (1939), which defined a director's fiduciary duties as requiring arm's length negotiation. 
shut down by money. ${ }^{247}$ Upon his victory as President, one of Ronald Reagan's first acts was to dismiss members of the Professional Air Traffic Controllers Organization who were attempting to bargain for a three-day weekend. ${ }^{248}$ After this, the National Labor Relations Board was restaffed by people opposed to collective bargaining, while Supreme Court jurisprudence ground the remainder of union rights down further. ${ }^{249}$

Nevertheless, labor's vote in corporate governance persisted. Douglas Fraser of the UAW served on the board of Chrysler from 1980 to 1984, treading a fine line between rescuing the company and recusing himself from negotiating collective agreements. ${ }^{250}$ In 1981, the UAW also proposed a labor representative on the American Motors Corporation board. The employers accepted UAW's proposal contingent on the government's approval. The Federal Trade Commission viewed this proposal as lawful. But the Department of Justice argued the Clayton Act of $1914 \S 8$, which prohibits interlocking directorates, was engaged if unions appointed board members to competing companies. It failed to provide credible evidence that there were any anti-competitive effects under similar European systems ${ }^{251}$ or that there was any way to recognize that local union appointees or direct elections by employees would present any problem. ${ }^{252}$ While the UAW did not press the issue, in 1982 Pan

\footnotetext{
247. Martin Gilens \& Benjamin I. Page, Testing Theories of American Politics: Elites, Interest Groups, and Average Citizens, 12 PERSP. POL. 564 (2014) (finding that legislation bears virtually no relation to people's preferences since 1981).

248. John M. Keynes, Economic Possibilities of Our Grandchildren (1930), in ESSAYS IN PERSUASION 358, 358-73 (1932).

249. Janus v. Am. Fed'n of State, Cty., \& Mun. Emps., Council 31, 138 S. Ct. 2448 (2018) (held 5 to 4 that unions could not collect fees from non-member workers who benefit from collective agreements); 14 Penn Plaza LLC v. Pyett, 556 U.S. 247 (2009) (held 5 to 4 that an employer can bind workers to submit to arbitration, with "arbitrators" chosen by employers to "decide" even statutory rights); Hoffman Plastic Compounds v. NLRB, 535 U.S. 137 (2002) (held 5 to 4 that NLRA of 1935 removed protection for undocumented workers to the fundamental right to organize a union); Mertens v. Hewitt Assocs., 508 U.S. 248 (1993) (held 5 to 4 that ERISA enabled employees to be denied the right to claim medical malpractice, when employers were the direct purchaser of a health care plan); Brown v. Hotel \& Rest. Emps. \& Bartenders Int'l Union Local 54, 468 U.S. 491 (1984) (held 5 to 4 on the NLRA of 1935 allowed states to ban union representatives who were not of "good moral character"); O'Connor v. Ortega, 480 U.S. 709 (1987) (held 5 to 4 that the Fourth Amendment allowed employees to be searched at work like criminal suspects); see, e.g., NLRB v. Yeshiva Univ., 444 U.S. 672 (1980) (held 5 to 4 that professors with nominal "management" input were deprived of the fundamental human right to collective bargaining).

250. See Douglas A. Fraser, Worker Participation in Corporate Government: The U.A.W.Chrysler Experience, 58 CHI.-KENT L. REV. 949 (1982); cf. Ronald M. Sharp, Codetermination: A Postmortem, 40 LAB. L.J. 323, 331-32 (1989).

251. For examples today, the Swedish Board Representation (Private Sector Employees) Act 1987 (SFS 1987:1245) $§ 6$ empowers unions to appoint board members. The German Codetermination Act $1976 \S \S 9$ and 18 enable unions to cast votes by default in companies with over 8,000 workers, but workers always have the right to opt out.

252. Cf. Davidson Douglas, Labor Unions in the Boardroom: An Antitrust Dilemma, 92 YALE L.J. 106, 117-25, (1982) (presenting a two-fold exemption test that (1) a representative should not be
} 
American Airways elected a union member to serve on its board. ${ }^{253}$ In 1984, the new UAW President, Owen Bieber, took up Fraser's board seat at Chrysler. ${ }^{254}$ The Pan American arrangement was ended by the board in 1991, but then revived in 1998 when the next UAW President, Stephen Yokich, joined ${ }^{255}$ during the merger with German corporation DaimlerBenz. ${ }^{256}$ In 1993, the United Steel Workers agreed to representation on five company boards for six years, ${ }^{257}$ and the USW leader, Lynn Williams, pushed for more whenever the opportunity arose. ${ }^{258}$ Compared to other OECD countries, these experiments alone mean the United States achieved one of the strongest traditions of codetermination. It was a remarkable feat in the face of the full force of the administrative state and the hostility of a Supreme Court, Department of Labor, Securities and Exchange Commission, and Department of Justice dominated by business interests.

Many board representation plans were entangled with share schemes, were without meaningful voice, ${ }^{259}$ and came with unacceptable risk. In a sample from 1998, Larry Hunter found that among 25 firms, all linked to share schemes, there was no majority of workers on a board. ${ }^{260}$ In 1999 , Robert McKersie recorded there were around 35 major representation plans in total. ${ }^{261}$ Critically, share schemes were exempted from ERISA's

a national union appointee, or (2) a full time official). It is notable that, unlike the serious issues with mutual funds discussed below, evidence of anti-competitive effects in European countries with codetermination laws and union appointees does not appear to exist.

253. Wall St. J., May 13, 1982, at 22.

254. Doron P. Levin, Chrysler to Cut Board; U.A.W. Chief Is Out, N.Y. TIMES, Mar. 14, 1991, at 1 .

255. John W. Budd \& James G. Scoville, The Ethics of Human Resources and INDUSTRIAL RELATIONS 270 (2005).

256. The corporation became Chrysler LLC in 2007, after being sold to Cerberus Capital Management. It went bankrupt in 2009: workers got board seats again, but it became a Fiat SpA subsidiary in 2014, now Fiat Chrysler Automobiles NV.

257. The Unions Step on Board, FIN. TIMES, Oct. 27, 1993.

258. Bruce E. Kaufman, An Interview with Steelworkers' President Lynn Williams, 22 J. LAB. RES. 145, 164-45 (2001).

259. $C f$. U.S. Gov't ACCOUNTABIlity OfFICE, GAO/PEMD-87-8, EMPloyeE Stock OWNERShIP Plans: Benefits AND COSTS OF ESOP TAX INCENTIVES FOR BROADENING STOCK OWNSERHIP 41-43 (1986) (In a survey of 3,000 ESOPs, around 15\% carried an employee involvement in decision-making.).

260. Larry W. Hunter, Can Strategic Participation be Institutionalized? Union Representation on American Corporate Boards, 51 INDUS. \& LAB. REL. REV. 557, 557-78 (1998); see also Elieen Appelbaum \& Larry W. Hunter, Union Participation in Strategic Decisions of Corporations, in EMERGING LABOR MARKET INSTITUTIONS FOR THE TWENTY-FIRST CENTURY 265, 282 tbl.8.1 (Richard B. Freeman et al. eds., 2005) (showing a list of companies with union-nominated directors).

261. Robert B. McKersie, Union Nominated Directors: A New Voice in Corporate Governance, in Negotiations and Change: From the Workplace to Society 223 (Thomas A. Kochan \& David B. Lipsky eds., 2003). 
requirements for prudent investment and diversification. ${ }^{262}$ These consequences were on display when the energy company, Enron, collapsed in December 2001. Enron's 20,000 employees had been encouraged, ${ }^{263}$ and partly required, ${ }^{264}$ to invest an average of $62.5 \%$ of their retirement savings in $401(\mathrm{k})$ plans in Enron itself. For this, the workforce had no board representation. Enron workers were not alone. One study found that employees invested an average of $29.6 \%$ of their pension savings in their employer. Procter \& Gamble's employees had 94.7\% invested, Coca-Cola's employees had 81.5\%, and General Electric's employees had $77.4 \%{ }^{265}$ Again, employees had no representation and were "horrifically underdiversified."266 The Enron economy, which sold ownership without power, was given an even bigger name by President George W. Bush in 2005: the "ownership society."267 The Enron economy, the ownership society, meant boardrooms, asset managers, and banks held onto economic privilege with other people's labor and other people's money.

It was easy to be cynical about labor's voice in corporate governance. In 1987, President Carter's former Labor Secretary, John Dunlop, said it was "damned insignificant and won't spread[,] . . codetermination is not about to sweep industrial relations in this country." ${ }^{268}$ Dunlop was also not planning to help. When President Clinton was elected, he appointed Dunlop to head a Commission on the Future of Worker-Management Relations. ${ }^{269}$ It recommended a unified definition of an "employee" to receive labor rights, as well as minor reforms to collective bargaining. It said nothing about board participation, though it did stoke debate about work councils. In 1992, the National Labor Relations Board decided that

262. ERISA § 404(a)(1)(C), 29 U.S.C. § 110469(a)(1)(C), requires diversification, but under (a)(2) this "is not violated by acquisition or holding qualifying employer securities" as defined under $\S 407(d)$.

263. David Millon, Worker Ownership through 401(k) Retirement Plans: Enron's Cautionary Tale, 76 ST. JOHN's L. REV. 835, 840 (2002) (“'II]n August 2001, CEO Ken Lay told employees, 'Now is the time to buy Enron shares' and, in September, he reiterated that the stock was a great bargain .... Lay himself sold shares worth twenty million dollars during the same period.").

264. ENRON Corp. SAVings Plan as Amended and Restated EFfective July 1, 1999, § III.1, 4, V.16(a).

265. Patrick J. Purcell, Cong. ReSearch SerV., RS21115, The EnRon BANKRuptCy AND EMPLOYER STOCK IN RETIREMENT PLANS 4 (2002).

266. John H. Langbein, Susan J. Stabile \& Bruce A. Wolk, Pension and Employee BENEFIT LAW 640-41 (4th ed. 2006).

267. President George W. Bush, Second Inaugural Address (Jan. 20, 2005) (“To give every American a stake in the promise and future of our country, we will ... build an ownership society. We will widen the ownership of homes and businesses, retirement savings and health insurancepreparing our people for the challenges of life in a free society.").

268. Bureau of National Affairs, DAILY LAB. REP., Nov. 30, 1987.

269. U.S. COMM'N ON THE Future OF WORKER-MGMT. Rel., Dunlop COMMISSION ON THE FUTURE OF WORKER-MANAGEMENT RELATIONS: FINAL REPORT (1994). 
"action committees" at Electromation Inc. violated NLRA of $1935 \S 8(\mathrm{a})(2) .{ }^{270}$ The committees heard complaints about pay or bonuses and had a majority of employee representatives, but the employer structured their proposals and paid the members. ${ }^{271}$ Dunlop said $\S 8(\mathrm{a})(2)$ should be "clarified" by Congress, but did not say how or why with any clarity. ${ }^{272}$ After the 1994 Congressional elections, Republicans proposed the Teamwork for Employees and Managers Act of 1995, which proposed to allow committees on any issue of "mutual interest" so long as they did not claim to become exclusive bargaining representatives. ${ }^{273}$ This was essentially a way, once more, to privatize labor voice, and reincarnate company unions. In 1996, President Clinton was forced to veto the Bill, though calls for $\S 8(\mathrm{a})(2)$ to be repealed or amended have persisted. ${ }^{274}$ The same issue resurfaced in 2014 at the Chattanooga, Tennessee plant of Volkswagen. At first, management suggested it wanted a "work council," though not clearly with autonomous rights that would ordinarily be found abroad. This led to an unprecedented campaign by Republican lobbyists and politicians to stop anything. Eventually, the UAW simply held a recognition ballot, where 626 workers voted in favor but 712 voted against. Instead, the UAW held and succeeded in a ballot for a segment of the plant. Management refused to bargain. ${ }^{275}$

Without meaningful voice on boards and in work councils, and with unions fighting hard, who held the votes in the American economy? In 1980, predictions were still widespread that labor's capital would grow, pensions or other collective funds could become democratic, and so would economic governance. This was not to be. A broad variety of corporate, trust, and contract pensions could be organized, either by collective agreement or the employer. ${ }^{276}$ But increasingly, people's savings were pressed into individual accounts, dominated by mutual firms. In 1982, one

270. Electromation Inc., 309 N.L.R.B. No. 163, 142 L.R.R.M. 1001 (1993).

271. EI du Pont de Nemours \& Co., 311 N.L.R.B. No. 88, 143 L.R.R.M. 1121 (1993) (deciding safety and health committees, because they were subject to a management veto, were an unlawful usurpation of labor organization functions); see Dennis M. Devaney, Electromation and du Pont: The Next Generation, 4 CORnell J. L. \& PUB. POL’Y 3, 14 (1994).

272. See U.S. COMM'N ON THE FUTURE OF WORKER-MGMT. REL., supra note 268, at 22, 27, 30-31. See, therefore, the dissenting view of Douglas A. Fraser, $i d$. at 32.

273. Teamwork for Employees and Managers Act of 1995, H.R. 743, 104th Cong. § 3 (1996).

274. See, e.g., Samuel Estreicher, The Dunlop Report and the Future of Labor Law Reform, 12 LAB. LAW. 117 (1996).

275. See Stephen J. Silvia, The United Auto Workers' Attempts to Unionize Volkswagen Chattanooga, 71 INDUS. L. REV. 600 (2018) (But note that the assessment at 605-06, suggesting it is unlawful under $\S 8(\mathrm{a})(2)$ to establish a work council, cannot be regarded as entirely accurate if, as in Germany, workers, not employers, take the initiative to set up work councils.).

276. See the excellent summary by Gerald P. Cunningham, The Employee Retirement Income Security Act of 1974 and Union Influence in Pension Fund Investment Decisions, 12 FORDHAM URB. L.J. 151 (1984). 
account of an election for four board vacancies at Prudential found the only four candidates were nominated by the board:

Eligible to vote were 18.4 million policyholders. Of these, $323 \mathrm{did}-$ virtually all of them employees of Prudential. Later in the same year, policyholders of the Equitable were called upon to choose among a field of 11 nominees to fill 11 board seats. An estimated 3,250,000 policyholders were eligible to vote but were not informed of the election; 6,400, mostly Equitable employees, voted by mail. ${ }^{277}$

Investment companies like Prudential or Equitable, increasingly running 401(k) plans, would be set up by firms under the Investment Advisers Act of 1940 without any real governance standards. The Investment Company Act of $1940 \S 16$ required policyholders to vote for the investment company board. But in practice, advisers selected the investment company's first board of directors and delegated the investment work back to the advisers. ${ }^{278}$

This was the model the Reagan administration aggressively sought to promote for labor's capital. In 1983, the Internal Revenue Service ruled that "surplus assets," which could be taken by a company when it closed down a pension scheme, meant anything in excess of current liabilities. ${ }^{279}$ In 1984, the Department of Labor and the Pension Benefit Guaranty Corporation issued termination guidelines for pension trusts. ${ }^{280}$ The closure of defined benefit pension funds was colossal, peaking in 1985. The Tax Reform Act of 1986 placed a cap on tax deferment in IRAs, encouraging the shift to mutual funds. ${ }^{281}$ The Single-Employer Pension Plan Amendments Act of 1986 enabled easy terminations. "Between 1980 and 1989, firms terminated more than 2,000 pension plans and used $\$ 20$ billion in 'excess' funds for their own purposes, leaving 1.6 million individuals . . 5 50 percent of what they would have received had their plans remained intact." 282 Those who did not lose their pensions got risky $401(\mathrm{k})$ plans. In $1979,401(\mathrm{k})$ assets were $2 \%$ of U.S. household assets,

277. ANDREW TOBIAS, INVISIBLE BANKERS: EVERything THE INSURANCE INDUSTRY NEVER WANTED YOU TO KNOW 35-36 (1982) ("Seven showed up at the election to vote in person.").

278. Jennifer S. Taub, Able but Not Willing: The Failure of Mutual Fund Advisers to Advocate for Shareholders' Rights, 34 J. CORP. L. 843, 849 (2009).

279. Internal Revenue Code $\S 1.401$ (b) permits "the employer to recover at the termination of the trust ... any balance which is due to erroneous actuarial computations during the life of the trust." Rev. Rul. 83-52, 1983-1 C.B. 87.

280. Teresa Ghilarducci, Labor's Capital: The EConomics and Politics of Private PENSIONS 90-91 (1992).

281. Mutual Funds, Brokers Taking A Bigger Slice of the IRA Pie, AM. BANKER, Mar. 10, 1986. 282. GHILARDUCCI, supra note 280, at 97. 
$3 \%$ in 1987 , but rose to $21 \%$ by $2009 .{ }^{283}$ Share ownership was transformed. ${ }^{284}$

Figure 5

US share ownership 1945-2018

Sources: Federal Reserve, Flow of Funds (2011) L.213; (2015) L.223 and (2018) L.223

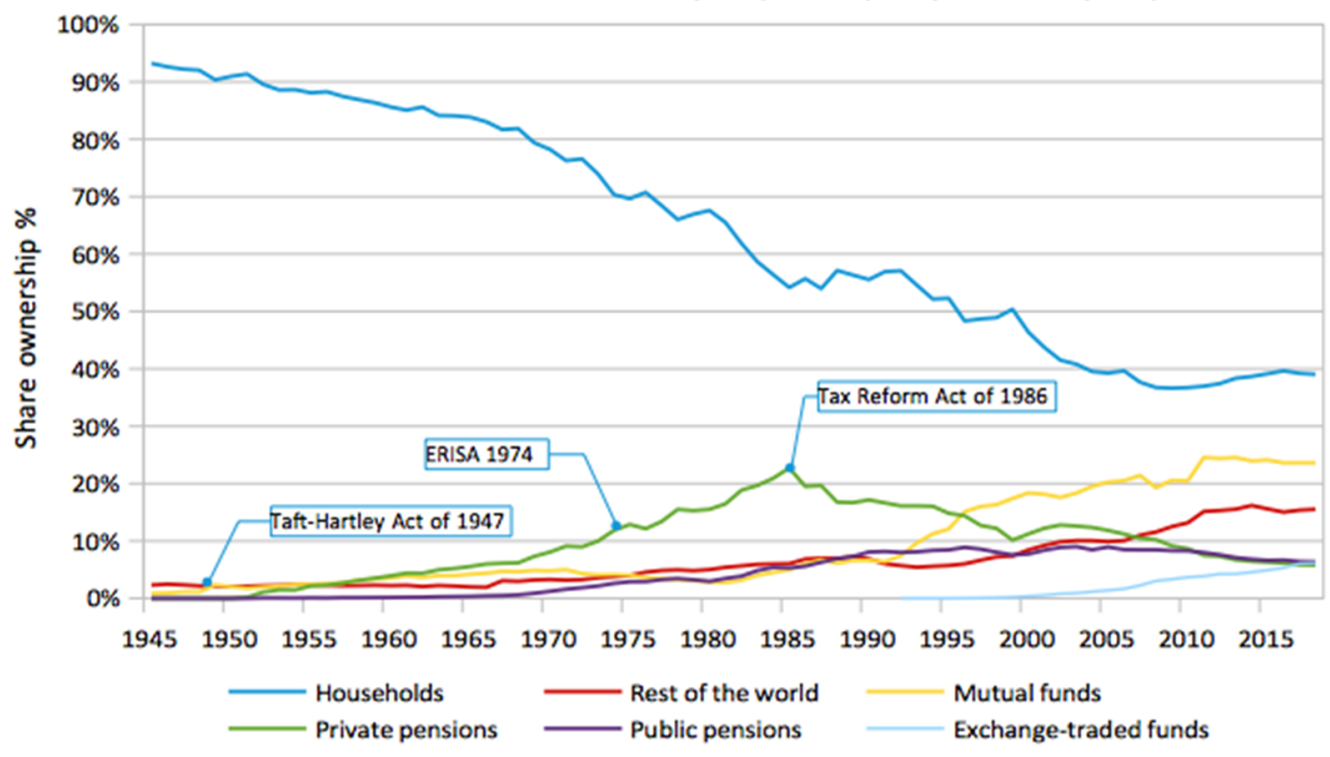

The turning point was 1985: private pensions (in green) went into decline, to be replaced in part by mutual fund firms (in yellow) selling individual 401(k)s. The largest termination in 1986 was made by Exxon: it took advantage of a tax-credit that was about to expire, seizing $\$ 1.6$ billion of its workers' pension money without paying corporate tax. ${ }^{285}$ The major asset management firms, especially Vanguard, State Street, and the new BlackRock, were on track to monopolize the priorities of corporate governance, and all with "other people's money."

283. INVESTMENT COMPANy Institute, INVESTMENT COMPANy FACTBOOK: A REVIEW OF TRENDS AND ACTIVITY IN THE INVESTMENT COMPANY INDUSTRY (50th ed. 2010).

284. The sources for the charts are BD. OF GOVERNORS OF FED. RESERVE SYS., FLOW OF FundS ACCOUNTS OF THE UNited STATES: ANNUAL Flows AND OUTSTANDINGS 2005-2010, at 85 tbl.L.223 (2011), and the updates in (2015) and (2018). Id. at 23 tbl.F.118, and 25 tbl.F.121 explain the concepts used at 85 tbl.L.213. The "private pension" figures included both defined benefit and defined contribution plans when they invested in shares, but only if it was managed independently or through a custodial bank. If money was placed into an open-ended investment company-run by an asset manager - it would show up under the mutual fund figures. The author has calculated percentages of total assets from the raw data and merged the federal, state and local pensions as "public." Various smaller categories are excluded.

285. GHILARDUCCI, supra note 280 , at 87. 
Employers were taking the votes on labor's capital as well. In 1989, a House of Representatives subcommittee on leveraged buyouts heard that trustees of single-employer pension plans were investing in junk bonds and terminating plans prematurely to make takeovers more attractive. ${ }^{286}$ Company directors used votes on employee pension money to defend against takeovers of friendly colleagues on other boards ${ }^{287}$ or simply to pursue pro-management policies. ${ }^{288}$ In 1989, Representative Peter Visclosky proposed a new $\S 403(a)(2)$ in ERISA, so that for singleemployer plans elected labor representatives and unions would have half the seats on pension boards. ${ }^{289}$ It was rejected. With similar provisions, the Workplace Democracy Act of 1992, sponsored by Bernie Sanders, was rejected, and so were its reintroductions up to $1999 .{ }^{290}$ A further bill, sponsored again by Peter Visclosky entitled the Employees' Pension Security Act of 2005, repeated to 2009, met the same fate. ${ }^{291}$

Where labor was represented, pensions were increasingly organized and active. ${ }^{292}$ In 1993, 45 of 50 state public pension funds had beneficiary representatives, although most were still appointed rather than elected. ${ }^{293}$ The reputation of appointed members had been tarnished, as employers used pensions to plug budget deficits by directing them to buy sub-prime government bonds. ${ }^{294}$ This led to a concerted move to ensure actual elections. ${ }^{295}$ By 1998 , out of 2,670 public retirement systems, there was an

286. Oversight Hearings on the Role of Pension Funds in Corporate Takeovers Before the Subcomm. on Labor-Mgmt. Relations of the H. Comm. on Educ. \& Labor, 101st Cong. (1989).

287. William M. O'BARR \& John M. Conley, Fortune and Folly: The Wealth and POWER OF INSTITUTIONAL INVESTING 182 (1992).

288. Roe, supra note 231, at 91-94.

289. Joint Trusteeship Act of 1989, H.R. 2664, 101st Cong. (1989).

290. Workplace Democracy Act of 1999, H.R. 1277, 106th Cong. (1999); see also H.R. 2012, 105th Cong. (1997); H.R. 1355, 104th Cong. (1995); H.R. 5126, 103d Cong. (1994); H.R. 6041, 102d Cong. (1992).

291. Employees' Pension Security Act of 2009, H.R. 4281, 111th Cong (2009); see also H.R. 5754, 110th Cong. (2008); H.R. 4055, 109th Cong. (2005).

292. Marleen O'Connor, Organized Labor as Shareholder Activist: Building Coalitions to Promote Worker Capitalism, 31 U. Rich. L. ReV. 1345 (1997); Stewart J. Schwab \& Randall S. Thomas, Realigning Corporate Governance: Shareholder Activism by Labor Unions, 96 Mich. L. REV. 1018 (1998). N.B. The SEC and courts ended social responsibility amendments under Rule $14 \mathrm{a}-8$.

293. Cynthia L. Moore, Public Pension Plans: The State Regulatory Framework (2d ed. 1993)

294. See generally Roberta Romano, Public Pension Fund Activism in Corporate Governance Reconsidered, 93 COLUM. L. REV. 795 (1993), where the proposed solution was apparently to give employees "more" control by transforming public pensions into defined contribution plans with guaranteed insurance contracts to mimic defined benefit outcomes. It is difficult, however, to detect how this alone would not simply place control in the hands of fund management families.

295. One aspect was the model Uniform Management of Public Employee Retirement Systems Act of $1997 \S 17$ (c)(3) suggesting pension plans disclose how its trustees were selected. See Steven L. 
average of $36 \%$ elected trustees, $15 \%$ ex officio trustees, and $44 \%$ appointed trustees. ${ }^{296}$ Adverse opinion still lingered, with some arguing that "public pension fund trustees lack significant financial incentives to maximize fund performance." 297 But the better view was that the increasingly "high activism of public pension funds" reflected "the way owners would tend to act. They lack the managerial command structure that private pensions have." 298 With size and motivation, public pensions drove better governance standards. ${ }^{299}$ This made them political targets. In 2005, Governor Arnold Schwarzenegger attempted to terminate the Californian plans and resurrect them as a form of 401(k) operation, until the plan was defeated by protests. ${ }^{300} \mathrm{He}$ was simply following the successful strategy of individualizing and outsourcing private pensions.

Although public or union pensions could be active, even acting together they would still invariably be a minority among registered stockholders in a company meeting: the others would typically be asset managers and, before 2010, banks acting as brokers. For example, in 2006, pensions campaigned against the reelection of Disney's Michael Eisner after he approved a $\$ 100$ million golden parachute for the ex-CEO Michael Ovitz. The motion to remove Eisner from office was, however, defeated by broker banks, who cast votes for their retail shareholders: votes on other people's money. ${ }^{301}$ This led to calls for the NYSE to tighten Rule 452, and it made a request to the SEC in $2006 .{ }^{302}$ The SEC finally condoned the

Willborn, Public Pensions and the Uniform Management of Public Employee Retirement Systems Act, 51 RUTGERS L. REV. 141, 145 (1998).

296. David Hess, Protecting and Politicizing Public Pension Fund Assets: Empirical Evidence on the Effects of Governance Structures and Practices, 39 U.C. DAVIS L. REV. 187, 196 (2005).

297. Marcel Kahan \& Edward B. Rock, Hedge Funds in Corporate Governance and Corporate Control, 155 UnIV. PA. L. REV. 1021 (2007). This referred to an old, slightly hostile article by Roberta Romano, supra note 293.

298. Roe, supra note 231, at 91-92 ("The high activism of public pension plans-pensions run for state employees - contrasts sharply with the relative passivity of private pensions. Public pensions persistently propose charter amendments, prod managers, and establish lobbying groups. Some of their actions may be political posturing, but I believe many are not. They are acting, roughly and imprecisely, the way owners would tend to act. They lack the managerial command structure that private pensions have.").

299. Cal. Pub. Emps.' Ret. Sys., Global Principles of Accountable Corporate Governance (2010) (requiring, for instance, under B6.1, removal of directors without cause and under A4, one share one vote).

300. Jim Wasserman, CA: Governor Ousts CalSTRS Appointees Who Oppose His Pension Plan, FREE REPUBLIC (Feb. 11, 2005), http://www.freerepublic.com/focus/f-news/1340769/posts [https:// perma.cc/7LNM-PKCH].

301. REPORT AND RECOMMENDATIONS OF THE PROXY WORKING GROUP TO THE NEW YORK STOCK EXCHANGE 9 (June 5, 2006), http://www.shareholdercoalition.com/sites/default/files/NYSE\% 20Proxy\%20Working\%20Grp\%20Rpt\%206-5-2006.pdf [https://perma.cc/M6E8-E34C].

302. The background is summarized briefly by Elisse B. Walter, Regulating Broker-Dealers and Investment Advisers: Demarcation or Harmonization?, 35 J. CORP. L. 1 (2009). 
change in $2009,{ }^{303}$ prohibiting brokers from voting on any election for directors, whether contested or not, unless they were registered as advisers under the Investment Company Act. ${ }^{304}$ The Dodd-Frank Wall Street Reform and Consumer Protection Act of $2010 \S 957$ then introduced a new Securities Exchange Act of $1934 \S 6(\mathrm{~b})(10)$. This prohibited brokers from using other people's shares to vote on anything that the Commission determined to be "significant" without express instruction from their customers, ${ }^{305}$ including director elections and executive pay.

Brokers could no longer vote, but asset managers still could, and the concentration of power has been spectacular. Invariably asset managers outsourced the actual casting of votes to proxy advisers, ${ }^{306}$ but they still controlled voting policy. By 2017, the three largest mutual firms, BlackRock, Vanguard, and State Street, if they combined the shares they held, would constitute the largest shareholder in 438 of the top 500 firms, and the largest in $40 \%$ of all companies. ${ }^{307}$ The largest five shareholders (mostly mutuals) owned an average $20.8 \%$ in the top-twenty corporations. ${ }^{308}$ It has been found that mutual firms have already caused rising consumer prices. ${ }^{309}$ This has been described as "the major new antitrust challenge of our time." 310

Even more than damage to competition, it is clear that conflicts of interest - by selling pension products to the firms in which they exercise voting rights - have become systemic. In a dataset from 2003 to 2011, a study found that the "presence of a fund with business ties can destroy up to $41 \%$ of the value enhancement" that comes from shareholder proposals. ${ }^{311}$ To maintain influence, mutual fund families significantly overweight the stocks of companies where the family provides $401(\mathrm{k})$

303. Eliminate Broker Discretionary Voting, Exchange Act Release No. 34-60215, 74 Fed. Reg. 33293, 3329395 (July 1, 2009).

304. Giving Proxies by Member Organization, New York Stock Exch., r. 452.11(19) (2018).

305. Dodd-Frank Wall Street Reform and Consumer Protection Act, Pub. L. No. 111-203, § 957, 124 Stat. 1376, 1906-07 (2010) (codified as amended at 15 U.S.C. § 78f(b) (2018)).

306. See generally Stephen Choi, Jill Fisch \& Marcel Kahan, The Power of Proxy Advisors: Myth or Reality?, 59 EMORY L.J. 869 (2010); Michael C. Schouten, Do Institutional Investors Follow Proxy Advice Blindly (Jan. 4, 2012) (unpublished Ph.D. dissertation, University of Amsterdam).

307. Eric A. Posner, Fiona M. Scott Morton \& E. Glen Weyl, Proposal to Limit the AntiCompetitive Power of Institutional Investors, 81 ANTITRUST L. J. 1, 2 (2017).

308. Lucian A. Bebchuk, Alma Cohen \& Scott Hirst, The Agency Problems of Institutional Investors, 31 J. ECON. PERSP. 89, 92 tbl.1 (2017).

309. Jose Azar, Martin C. Schmalz \& Isabel Tecu, Anti-Competitive Effects of Common Ownership, 73 J. Fin. 1513 (2018).

310. Posner, Morton \& Weyl, supra note 306, at 2. The authors' proposal, despite the prescient antitrust analysis, of limiting shareholdings to $1 \%$ would be highly damaging and disproportionate to the problem. This essentially mirrors the General Motors "Treaty of Detroit" plan, supra at Part I.C.

311. Dragana Cvijanovic, Amil Dasgupta \& Konstantinos Zachariadis, Ties that Bind: How Business Connections Affect Mutual Fund Activism, 76 J. Fin. 2933 (2016). 
plans. ${ }^{312}$ For over four decades, ${ }^{313}$ mutual funds have been empowered to engage in mass self-dealing, using shareholder votes to close collective DB schemes, open 401(k) plans, and so inflate the fees they earn by giving everyone an individual account: "smashing and scattering" pensions wherever they go. ${ }^{314}$

Mutual firms do not only use their votes for mass self-dealing: they crush proposals that do not match the political preferences of fund managers. In 2009, Jennifer Taub found that "the greater the dependency of the Adviser upon the [defined contribution] channel for asset management business, the less likely the fund family will be to support shareholder-sponsored governance resolutions." 315 Indeed, Vanguard, BlackRock, and State Street have almost identical voting guidelines. ${ }^{316}$ Through sheer inertia they routinely opposed all attempts to restrain spiraling executive pay, advance employment rights, control corporate political donations, or stop climate damage. ${ }^{317}$ Mutual funds support management $90 \%$ of the time, and spend almost nothing to do it: Vanguard employed just fifteen people for engagement and voting in 13,000 companies, BlackRock twenty people for 14,000 companies, and State Street under ten people for 9,000 companies. ${ }^{318}$ Less than fifty people dominate and abuse the U.S. economy, all unelected.

\section{THE MYTH OF SHAREHOLDER LEGITIMACY}

The concentration of power in the modern economy has followed no coherent historical or economic logic. Instead of arising through fair competition, voting was shaped by legal suppression of labor's voice, compounded upon capital's unequal bargaining power. Though the history is clear, are there political justifications for asset managers monopolizing the votes in the economy today?

312. Lauren Cohen \& Breno Schmidt, Attracting Flows by Attracting Big Clients: Conflicts of Interest and Mutual Fund Portfolio Choice (Harvard Bus. School, Working Paper No. 08-054, 2007).

313. Recall RIFKIN \& BARBER, supra note 190, at 116 on Firestone and Chase, supra at Part I.C.

314. David Webber, The Real Reason the Investor Class Hates Pensions, N.Y. TIMES (Mar. 5, 2018), https://www.nytimes.com/2018/03/05/opinion/investor-class-pensions.html (full story told in WEBBER, supra note 17 , chs. 1, 7, 8).

315. Jennifer S. Taub, Able but Not Willing: The Failure of Mutual Fund Advisers to Advocate for Shareholders' Rights, 34 J. CORP. L. 843, 847 (2009).

316. Dorothy Shapiro Lund, The Case Against Passive Shareholder Voting, 43 J. CORP. L. 101, 124 (2018).

317. Scott Hirst, Social Responsibility Resolutions, 43 J. CORP. L. 217, 224-27 (2018) (showing tables of resolutions and the voting record of support on political spending disclosure and carbon emission disclosure).

318. Sarah Krouse, David Benoit \& Tom McGinty, Meet the New Corporate Power Brokers: Passive Investors, WALL ST. J. (Oct. 24, 2016), https://www.wsj.com/articles/the-new-corporatepower-brokers-passive-investors-1477320101. 
Like Louis Kelso's view that holding shares is the passport to corporate citizenship, ${ }^{319}$ conventional wisdom in corporate governance, at least in the United States, ${ }^{320}$ is dominated by an idea of legitimacy for "shareholder primacy" because it is said shareholders bear the greatest risks in bankruptcy. In 1979, Jensen and Meckling argued that because a shareholder is (supposedly) "the residual claimant on the firm's cash flows" - or the party to be paid last upon a corporation's bankruptcy-the shareholder is the best monitor of the corporation. The "monitoring of management will be far less efficiently performed" by workers because they, said Jensen and Meckling, are not the "residual claimant." ${ }^{321}$ In 1983, Easterbrook and Fischel argued that shareholders monopolize votes because "[v]oting flows with the residual interest in the firm" and, if laws do anything else, "there will be a needless agency cost of management." 322 In 1984, Oliver Williamson suggested that shareholders make the only "asset-specific" investments in corporations that cannot be protected without monopolizing votes for the board of directors. While workers' interests could apparently be protected through job security, the "capital is always at hazard." 323

These theories have become major canons of corporate governance for at least three decades, but rest on a premise that is evidently wrong: shareholders usually bear no risk and make no firm-specific investments. Asset managers control shareholder voting rights with other people's money. ${ }^{324}$ This is why theories of shareholder primacy were rejected by Berle and Means, and from the New Deal to the 1970s. ${ }^{325}$ Sometimes, a

319. KELSO \& ADLER, supra note 14, at 167.

320. Cf. Simon Deakin, The Corporation as Commons: Rethinking Property Rights, Governance and Sustainability in the Business Enterprise, 37 QUEEN's L.J. 339 (2012); Thomas Raiser, The Theory of Enterprise Law in the Federal Republic of Germany, 36 AM. J. CoMP. L. 111 (1988). But also in the United States, see Lynn A. Stout, The Corporation as Time Machine: Intergenerational Equity, Intergenerational Efficiency, and the Corporate Form, 38 SEATTLE U. L. REV. 685 (2015), which holds up Oxford University - whose governance is dominated by its employees — as a central example for good long-term governance.

321. Jensen \& Meckling, supra note 244, at 485-86.

322. Frank H. Easterbrook \& Daniel R. Fischel, Voting in Corporate Law, 26 J. L. ECON. 395, 409 (1983). The authors also suggest that this is the reason that a one-share, one-vote norm prevails. Basic historical understanding shows such a norm does not prevail in absence of regulation. See EWAN MCGAUGHEY, PARTICIPATION IN CORPORATE GOVERNANCE ch. 5 (2014).

323. Oliver E. Williamson, The ECONOMIC INSTITUTIONS OF CAPITALISM 29 (1985); Oliver E. Williamson, Corporate Governance, 93 YALE L.J. 1197, 1210 (1984).

324. $C f$. John Stuart Mill, PrinciPles of Political ECONOMY ch. 15, § 1 (1848), (making the point that capital bears risk, but believed, at Book IV, ch. 7, $\S 4$, "the relation of masters and workpeople will be gradually superseded by partnership, in one of two forms: in some cases, association of the labourers with the capitalist; in others, and perhaps finally in all, association of labourers among themselves").

325. E.g., BERLE \& MEANS, supra note 4, at 353-56 (arguing that corporations must serve, not a self-enriching group of directors or shareholders, but "the paramount interests of the community"). 
claim is added that multiple interest groups on boards will quarrel with one another, leading to inefficient management. ${ }^{326}$ Shareholders, it is said, should monopolize governance because they have a homogenous interest in maximizing profits, while workers (ostensibly) have more heterogeneous views. ${ }^{327}$ Even if interest-heterogeneity could be measured, ${ }^{328}$ or the claim that multiple interest groups lead to inefficiency were backed by empirical evidence, ${ }^{329}$ asset manager interests are diametrically opposed to those of the true investors. With ownership separated from control, ${ }^{330}$ asset managers profit from their office, charging fees in markets they vote to rig, not from doing good work. ${ }^{331}$ Even if one accepts the evidence-free theory that asset managers do bear risk, or share interests with other shareholders, most people know the risk of losing a job is more serious than the risk of losing money on one insolvent company in a diversified share portfolio. ${ }^{332}$ Job-risk weighs more in people's lives than capital-risk. The monopolization of shareholder votes by asset managers is not a system that emerged in a competitive environment, ${ }^{333}$ but one backed by the coercive power of federal law and the unequal bargaining power of captured capital.

But would shareholder monopolization be more legitimate if the true investors of capital, not asset managers, alone held all voting rights? This

326. HENRY HANSMANN, THE OWNERSHIP OF ENTERPRISE 111-12 (1996) (“[T]he board is not used for making the particular types of decisions where workers and shareholders have the most strongly conflicting interests, and where the workers have the most strongly conflicting interests among themselves."); accord JOHANNES C. D. ZAHN, WIRTSCHAFTSFÜHRERTUM UND VertRAGSETHIK IM NEUEN AKTIENRECHT 15 (1934) ("Sie haben dabei richtig erkannt, daß es im gewerblichen Leben entscheidend auf die führernde Einzelpersönlichkeit ankommt und daß man mit der Zersplitterung der Leitung den Keim der Schwäche in ein Unternehmen hineinliegt." Referring to American business, "They have rightly recognised that in business life, that the personality of the leader is decisive and that any division of the leadership carries the seed of corporate weakness."); Vagts, supra note 126, at 52-53.

327. HANSMANN, supra note 325 , at $62-63,97$.

328. Id. at 97 says it is a social construct.

329. Cf. Larry Fauver \& Michael E. Fuerst, Does Good Corporate Governance Include Employee Representation? Evidence from German Corporate Boards, 82 J. FIN. ECON. 673, 678-81 (2006); Tom Schuller \& Jeff Hyman, Trust Law and Trustees: Employee Representation in Pension Schemes, 12 InDUS. L.J. 84, 91-93 (1983) (on codetermined pension boards); 403 Parl Deb HL (6th ser.) (1979) cols. 1158-66 (U.K.) (the U.K. Post Office).

330. Cf. Ronald J. Gilson \& Jeffrey N. Gordon, The agency Costs of Agency Capitalism: Activist Investors and the Revaluation of Governance Rights, 113 COLUM. L. REV. 863 (2013); Leo Strine, Toward Common Sense and Common Ground? Reflections on the Shared Interests of Managers and Labor in a More Rational System of Corporate Governance, 33 J. CORP. L. 1, 6 (2007).

331. BERLE \& MEANS, supra note 4, at 122.

332. This situation obviously changes in a company like Enron.

333. HANSMANN, supra note 325 , at 111 , like Jensen \& Meckling, supra note 244 , also claims that "codetermination has been imposed upon German firms by force of law; no similar system seems to have been adopted by any significant number of firms either inside or outside of Germany in the absence of compulsion." This is mistaken because German codetermination came from collective agreements, which were later codified in law. See McGaughey, supra note 16. 
is doubtful, precisely because the true investors of capital are usually workers saving for retirement, and people want voice at work as well as in their savings. In 2018, in a survey of 3,330 likely voters, 53\% supported having the right to vote for representatives on the boards of large companies, while just $22 \%$ were opposed, and $25 \%$ did not know. ${ }^{334}$ In addition, survey data in 1995 suggested thirty to 40 million American workers wanted union representation, and 80 million wanted independent collective voice in their workplace. ${ }^{335}$ The trend, despite the declining density of membership, has been towards more support for unions. ${ }^{336}$ In 2017 , a survey of 3,915 people found $48 \%$ of interviewees would join a union if they could. ${ }^{337}$ This strongly suggests that the extreme position of shareholders monopolizing the votes in corporate governance, let alone asset managers, is deeply illegitimate in the United States today.

\section{RECREATING THE LABORATORIES OF ENTERPRISE}

Articulated support for labor's voice in corporate governance has grown so much ${ }^{338}$ that it is necessary to ask, are there any barriers to law reform? At first glance the barriers may seem tremendous, because it is commonplace that labor law has "ossified" at a federal level, ${ }^{339}$ for at least four reasons. First, money buys almost all sides of the political spectrum, ${ }^{340}$ and the rich and corporate boards oppose labor rights. Second, federal legislation must pass the House, Senate, and President that, due to different election times, are often politically divided. Third, the Senate filibuster and cloture rules mean sixty of one hundred votes are needed to make law. Since 1980, Democrats had a legislative majority in just four years. Fourth, even if a law passes, the Supreme Court has

334. Dylan Matthews, Workers Don't Have Much Say in Corporations. Why Not Give Them Seats on the Board?, Vox (Apr. 6, 2018), https://www.vox.com/2018/4/6/17086720/poll-corporateboard-democracy-worker-council-codetermination-union-labor [perma.cc/WFC5-KE7L].

335. Joel Rogers \& Wolfgang Streeck, Workplace Representation Overseas: The Works Councils Story, in WORKING UNDER DifFERENT Rules 97, 97-98 (Richard B. Freeman ed., 1995).

336. Alex Bryson \& Richard B. Freeman, Workers Needs and Voice in the US and UK (Nat'1 Bureau Econ. Research, Working Paper No. 12310, 2006) (citing a 2005 Zogby poll that reported 35\% would vote for union, while a 2004 Zogby poll found $45 \%$ would support a union).

337. Thomas A. Kochan et al., Voice Gaps at Work, Options for Closing Them, and Challenges for Future Actions and Research (Int'1 Labour Review, Working Paper, 2018).

338. E.g., ElizABeth ANDERson, Liberty, Equality, AND Private Government (2015) (referring to codetermination as "highly successful"); Stephen F. Befort, A New Voice for the Workplace: A Proposal for an American Works Councils Act, 69 Mo. L. REV. 607 (2004); Charles B. Craver, Mandatory Worker Participation is Required in a Declining Union Environment to Provide Employees with Meaningful Industrial Democracy, 66 GEO. WASH. L. REV. 135 (1997); Kenneth G. Dau-Schmidt, Promoting Employee Voice in the American Economy: A Call for Comprehensive Reform, 94 MARQ. L. REV. 765 (2011). (2002).

339. Cynthia L. Estlund, The Ossification of American Labor Law, 102 COLUM. L. REV. 1527

340. See Buckley v. Valeo, 424 U.S. 1 (1976); McGaughey, supra note 21. 
assumed an ostensible right (based on theories of "unconstitutionality" that its members invent) ${ }^{341}$ to strike down legislation. Judges tend not to be from working-class backgrounds and have used their self-endowed power to suppress labor voice.

All this said, the same conditions do not prevail among the states, where the political balance is very different than in Washington D.C. Before the federal government recovers its capacity to act, could the states recreate themselves as laboratories of enterprise? In 1982, Clyde Summers argued that the federal government would have to legislate for codetermination because, otherwise, corporations would move to avoid state law, and any such laws could conflict with federal labor and antitrust law. ${ }^{342}$ Of course, states could be interested not only (1) in workers on boards, but also (2) in advancing labor's voice in capital, and (3) in work councils. So, do legal barriers exist for democracy in America at work?

First, states can in fact enact codetermination laws without any real barrier. There is no reason in constitutional or federal law to prevent it, and this is especially true since Massachusetts has had a codetermination law, however voluntary, since 1919. The dominant view is that the National Labor Relations Act of $1935 \S 8(\mathrm{a})(2)$ also presents no barrier to corporate board participation. ${ }^{343}$ Worker representation on corporate boards is one of the most important achievements of collective bargaining, which the NLRA promotes. But would corporations move to other states to avoid a codetermination law? The empirical evidence from the European Union, which has similar incorporation freedom, suggests such predictions are exaggerated, ${ }^{344}$ and codetermination has steadily spread. Firms have very good reasons to maintain the trust, confidence and participation of their workforces because it is clear that worker participation raises productivity, and therefore the potential for profit for

341. Recent examples include District of Columbia v. Heller, 554 U.S. 570 (2008), striking down a 30-year ban on handguns in Washington D.C., and Citizens United v. Federal Election Committee, 558 U.S. 310 (2010), striking down limits on corporations spending money to influence elections. The source of the U.S. Supreme Court's authority to strike down legislation is the U.S. Supreme Court case Marbury v. Madison, 5 U.S. (1 Cranch) 137 (1803), implying the Court's power into Article 3, Section 2 of the U.S. Constitution, to strike down laws by adopting, in substance, the reasoning of $D r$. Bonham's Case, (1610) 77 Eng. Rep. 646; 8 Co. Rep. 113b.

342. Clyde Summers, Codetermination in the United States: A Projection of Problems and Potentials, 4 J. COMP. CORP. L. SEC. REG. 155, 157 (1982).

343. E.g., J. Bautz Bonanno, Employee Codetermination: Origins in Germany, Present Practice in Europe and Applicability to the United States, 14 HARV. J. LEGIS. 947 (1976); Brian Hamer, Serving Two Masters: Union Representation on Corporate Boards of Directors, 81 Colum. L. Rev. 639 (1981); Katherine Van Wezel Stone, Labor and the Corporate Structure: Changing Conceptions and Emerging Possibilities, 55 UnIV. CHI. L. Rev. 73, 126-38 (1988); Erik B. Wulff, The West German Model of Codetermination Under Section 8(a)(2) of the NLRA, 51 IND. L.J. 795 (1976).

344. Simon Deakin, Legal Diversity and Regulatory Competition: Which Model for Europe?, 12 EUROPEAN L.J. 440 (2006). 
everyone. Capital moves faster than labor, but ideas move faster still. Ideas also stick. The states that make up nearly two-thirds of all incorporations are Delaware, California, and New York. ${ }^{345}$ These states lean towards Democratic majorities. If they or others chose, they could require that a percentage of board seats are reserved for employees, adapting the models in the Reward Work Act or the Accountable Capitalism Act. Alternatively, state laws could require that employees as well as shareholders have a percentage of votes at each annual general meeting, or they could do both. ${ }^{346}$

Second, could states ensure that the votes bought by labor's capital are cast only in accordance with the preferences of elected representatives of workers and beneficiaries? While the Employee Retirement Income Security Act of 1974 has broad preemption provisions, ${ }^{347}$ its absence of governance rules means it cannot preempt state law that requires governance rights for labor: this logically remains the domain of state trust or corporate law. Many trusts and mutual fund corporations are established in Massachusetts and Delaware. ${ }^{348}$ If states chose, first, they could follow the model of the Workplace Democracy Acts or the Employees' Pension Security Acts to require one-half representation of beneficiaries in any single-employer or other form of pension plan. A federal model to do so is readily available in the Taft-Hartley Act of $1947 \S 302(\mathrm{c})(5)(\mathrm{B}) .^{349} \mathrm{In}$ addition, states could require that corporate governance departments of

345. Lucian Bebchuk, Alma Cohen \& Allen Ferrell, Does the Evidence Favor State Competition in Corporate Law?, 90 CAL. L. REV. 1775, 1809-10 (2002) (Showing Delaware 57.75\%, California $4.33 \%$, New York $3.46 \%$, Nevada 3.32\%, Minnesota 2.73\%, Florida $2.53 \%$, Texas $2.25 \%$, Colorado $2.02 \%$, Pennsylvania $1.9 \%$, Maryland $1.81 \%$, and Ohio $1.72 \%$. By contrast, the real seats of corporations are California 19.2\%, Texas 8.97\%, New York 8.82\%, Maryland 5.51\%, Florida 5.02\%, New Jersey $4.76 \%$, Pennsylvania 3.8\%, Illinois 3.69\%, Minnesota 3.25\%, and Colorado 3.08\%.).

346. State corporation law typically suggests that shareholders exercise appointment or removal rights over the board. See, e.g., DEL. CODE. tit. 8, § 141(k) (2016) (removal "by the holders of a majority of the shares"); CAL. CORP. CODE $\S 301$ (2016) (directors elected "at each annual meeting of shareholders."); CAL. CORP. CODE $\S 303$ (directors may be removed "if the removal is approved by the outstanding shares" subject to various rules); CAL. CORP. CODE $\S 304$ (10\% of shareholders can apply for removal by court for fraud or gross abuse); N.Y. BUS. CORP. LAW § 703 (2016) (“At each annual meeting of shareholders, directors shall be elected."); N.Y. Bus. CORP. LAW § 706 (removal "for cause by a vote of shareholders"); see also MODEL BUS. CORP. ACT (AM. BAR Ass'N 2016) (The Model Act is mirrored in many states. It suggests in $\S 8.03(\mathrm{c})$, "Directors are elected at the first annual shareholders' meeting," in $\S 8.08(\mathrm{a})$, "[S]hareholders may remove one or more directors with or without cause," and in $\S 8.08$ (b), "If a director is elected by a voting group of shareholders, only the shareholders of that voting group may participate in the vote to remove that director."). These Acts can be amended to say "shareholders or employees" have these powers, with the percentage of votes in annual meetings, or board seats, to be allocated to employees by a company's bylaws.

347. 29 U.S.C. § 1144(a) (1974) (noting that ERISA "supersede[s] any and all State laws insofar as they may now or hereafter relate to any employee benefit plan").

348. Scott Hirst, Social Responsibility Resolutions, 43 J. CORP. L. 217, 222 (2018).

349. Cf. Shaw v. Delta Air Lines, Inc, 463 U.S. 85 (1983) (holding that a New York law was preempted only insofar as it prohibited practices that were lawful under federal law). 
mutual funds are wholly elected by the holders of 401(k) accounts. Most importantly, states have the right to enforce fiduciary laws to stop any possibility of a conflict of interest between a mutual firm's voting and its sale of pension products to companies. ${ }^{350}$ States could require that no asset manager casts votes on other people's money without express instructions or without following the wishes of elected representatives of beneficiaries. A model that can be adapted is the Dodd-Frank Act $\S 957$, which restricts brokers voting without instructions.

Third, could states require that employees within their territory have a right to elect work councils with binding rights, for instance, in working time, social funds, or dismissals? ${ }^{351}$ Fundamentally, there appears to be no reason why a truly independent work council, which is not dominated or funded by the employer, cannot be established by collective agreement or law. ${ }^{352}$ The NLRA of $1935 \S 8(\mathrm{a})(2)$ prohibits a body where there is "actual domination" by an employer, so bona fide cooperative efforts are not hindered, ${ }^{353}$ nor are genuine initiatives for "a meaningful avenue for the expression of employee wishes." ${ }^{, 354}$ If there is not merely an expression of wishes, but binding rights resulting from elected work council decisions, it is inconceivable that this touches the mischief that Senator Wagner and Congress intended to resolve. The episode at the Volkswagen plant in Chattanooga, Tennessee from 2014 to 2016 underlines the point. The only credible argument that a work council would be preempted was if the policy ensured that management could veto whatever the "work council" decided. ${ }^{355}$ Management vetoes would make the work council a sham under a genuine work council law. If states simply adopted the model that the U.S. government helped write for Germany in $1946,{ }^{356}$ they would meaningfully advance voice at work.

350. See Halebian v. Berv, 931 N.E.2d 986 (Mass. 2010); Saminsky v. Abbott, 185 A.2d 766 (Del. Ch. 1961).

351. For an indicative list, see the Betriebsverfassungsgesetz (BetrVG) [German Works Constitution Act], Jan. 15, 1972, BGBL. I at 2518, $\S \S 87,111$ (Ger.) (as amended) (listing thirteen issues plus arrangements for dismissal decisions to go to arbitration or a court if the employee-elected work council objects).

352. The funding of work councils appears to be the only difference between the system that emerged in Germany following Control Council Law No. 22, as the employer must provide financing for work council activities: this is not viewed as compromising the work council's independence.

353. Modern Plastics Corp. v. NLRB, 379 F.2d 201 (6th Cir. 1967).

354. Hertzka and Knowles v. NLRB, 503 F.2d 625, 631 (9th Cir. 1974).

355. Cf. Benjamin Sachs, A New Way Forward for VW-Tennessee, ONLABOR, May 20, 2014, https://onlabor.org/a-new-way-forward-for-vw-tennessee/ [perma.cc/3QWH-LEHD].

356. Control Council Law No. 22 Works Councils, Apr. 10, 1946, OfFicial GAZETTE OF THE CONTROL COUNCIL FOR GERMANY 1945-1946, at 133-36 (1946), LSE Archives 43 (R498). 


\section{CONCLUSION}

Can there be democracy in America at work? The answer must be yes. The United States has the world's oldest codetermination law continually in force. Workers have been on the boards of manufacturing, retail, automobile, aeroplane, steel, and food companies. Had labor not been continually suppressed by hostile courts and governments, unions would have pressed for workers on boards in telecommunications, supermarkets, beverage production and more. The use of labor's capital by union and public pension funds for positive social policies counts among the most sophisticated and organized in the world. ${ }^{357}$ In the broad sweep of history, over half of the Amendments to the Constitution, nine out of seventeen since the Declaration of Independence, have directly concerned the right to vote. ${ }^{358}$ The right to vote, not just in politics but also at work, in retirement, and in the economy holds no less constitutional significance. In this like so much else, America is still a land of opportunity.

As the empirical case grows, and as labor law becomes central to twenty-first century corporate governance, ${ }^{359}$ it is likely that the opposition to labor's voice in the economy will become increasingly based on emotional appeal. This Article has made the case that the claims of labor voice being foreign, inefficient, unpopular, or unlawful are evidence-free. But if history or reality will not comply, an opponent's best alternative is to build contempt for reason. ${ }^{360}$ This is the tragic state of political debate today. At its core, a more democratic economy is essential to preserve democracy in politics. Escalating economic inequality means a house more divided, and the laws which underpin corporate governance are probably the most important pre-tax causes of escalating inequality today. ${ }^{361}$ Democracy ensures that governance is in the hands of the many, not the few, and that informed, democratic deliberation, with reasoned

357. See generally WEBBER, supra note 17.

358. Those Amendments include the Twelfth (presidential election procedure), Thirteenth (abolishing slavery), Fourteenth (defining citizenship), Fifteenth (vote regardless of race), Seventeenth (direct Senator elections), Nineteenth (vote regardless of gender), Twenty-Third (enfranchising D.C. voters), Twenty-Fourth (prohibiting poll taxes), and Twenty-Sixth (enfranchising people over eighteen years old).

359. $C f$. Robert CHARles Clark, CORPORATE LAW 32 (1986) (“[E]ven if your aim is not to understand all of law's effects on corporate activities but only to grasp the basic legal 'constitution' or make-up of the modern corporation, you must, at the very least, also gain a working knowledge of labor law.").

360. See Timothy Snyder, The RoAd to UnFreedom: RuSsia, Europe, America 244-49 (2018) (on web: "robots who told [American voters] what they wanted to hear").

361. Cf. Elizabeth Warren, Companies Shouldn't Be Accountable Only to Shareholders, WALL ST. J. (Aug. 14, 2018), https://www.wsj.com/articles/companies-shouldnt-be-accountable-only-toshareholders-1534287687 (noting "the wealthiest $10 \%$ of U.S. households own $84 \%$ of Americanheld shares"). 
social debate, provides the basis for freedom, personal autonomy, and liberty because this is what the overwhelming majority of people want for themselves. "We may have democracy," Louis Brandeis once said, "or we may have wealth concentrated in the hands of a few, but we can't have both. ${ }^{362}$ The truth is, the corporation has already socialized property, ${ }^{363}$ ensuring that individuals can freely invest their savings, and invest their labor, as one. Through the strength of their common endeavor, people can achieve social and economic progress, and better together than they would alone. But if property is social, it is sorely unequal because it is not yet democratic. The problem is no longer merely the socialization of ownership, but the democratization of power. Democracy in America needs to work. 